\title{
Theoretical and practical aspects of biological sulfate reduction: a review
}

\author{
Brahmacharimayum B. ${ }^{1}$, Mohanty M.P. ${ }^{2}$ and Ghosh P.K. ${ }^{2, *}$ \\ ${ }^{1}$ Centre for the Environment, Indian Institute of Technology Guwahati, 781039, India \\ ${ }^{2}$ Department of Civil Engineering, Indian Institute of Technology Guwahati, 781039, India \\ Received: 09/01/2018, Accepted: 18/02/2019, Available online: 20/02/2019 \\ *to whom all correspondence should be addressed: e-mail: pkghosh@iitg.ernet.in \\ https://doi.org/10.30955/gnj.002577
}

\section{Abstract}

The major environmental impact of discharge of excessive quantities of sulfate is the pollution of the surface and ground water supplies which can be harmful to life forms and therefore the need for an efficient treatment system arises. Biological sulfate reduction offers the advantage of less sludge production, less operational cost and efficiency in comparison to the physicochemical processes. Depending upon the feeding and operating conditions as well as microbes used, a number of intermediates are formed that may greatly affect the overall performance of bioreactor. This article extensively explores the bacterial community, formation of intermediates and desirable end products, theoretical and practical aspects of various environmental and operating conditions, and performance of bioreactors used for treating sulfate rich wastewater along with process biokinetics involved in biological sulfate reduction.

Keywords: Sulfate reduction, sulfide, sulfate reducing bacteria, bioreactors, biokinetics.

\section{Introduction}

Sulfate is one of the most abundant anions present in the environment. It appears naturally with various water streams in dissolved forms or as insoluble salts like barite $\left(\mathrm{BaSO}_{4}\right)$, epsomite $\left(\mathrm{MgSO}_{4} \cdot 7 \mathrm{H}_{2} \mathrm{O}\right)$ and gypsum $\left(\mathrm{CaSO}_{4} \cdot 2 \mathrm{H}_{2} \mathrm{O}\right)$, as well as generated through oxidation of sulfide ores in acid mine drainage (AMD) (Neculita et al., 2007). It is also discharged in effluents from various industries such as mining, animal husbandry, food processing, pulp and paper wastewaters, dye and detergent manufacture industries (Lens and Hulshoff Pol, 2000). Both physico chemical and biological treatment options are practiced for the remediation sulfate rich wastewater. Amongst the various treatment options, bioreduction of sulfate is considered as an efficient method (Liamleam and Annachhatre, 2007), owing to less sludge handling, flexibility of operation along with low cost of treatment. It is a microbial driven process in which a specialized group of microorganisms called sulfate reducing bacteria (SRB) are responsible (Postgate, 1984).
The SRB represent a diverse group of obligate anaerobes which thrive in the anoxic environments containing organic materials and sulfate (Tang et al., 2009). The basic mechanism in sulfate reduction lies with the utilization of carbon source/s such as hydrogen, ethanol, methanol, glucose, lactate, sugarcane, and wood etc. as electron donor/s and sulfate as terminal electron acceptor. However depending upon the process conditions, many factors such as $\mathrm{pH}$, temperature, influent $\mathrm{COD} / \mathrm{SO}_{4}{ }^{2-}$ ratio, and electron donor may influence the outcome of bacterial substrate competition and sulfate reduction (de Smul et al., 1999). For example the SRB have been seen to thrive in various sediments characterized by very low temperatures and availability of organic matter (Kristensen et al., 2000; Weber et al., 2001). Even the presence of heavy metals in the system (Sani et al., 2001) and undissociated sulfide have been seen to affect the process efficiency as a whole (Lens and Hulshoff, 2000; Okabe et al., 1995). A number of reactor configurations such as batch reactor, sequential batch reactors, anaerobic filters, fluidized bedreactors, membrane bioreactors, hybrid anaerobic reactors and Upflow Anaerobic Sludge Blanket (UASB) reactors used for the biological reduction of sulfate have been described in the literature, each kind of reactor configuration providing its own flexibility in terms of operation and efficiency (Kaksonen and Puhakka, 2007). Various studies on biokinetics of sulfate reduction has been done for the estimation of biokinetic coefficients such as specific growth rate, half velocity constant, decay rate etc while utilizing various micro-organisms and electron donors. The biokinetic analysis assists in the prediction of population dynamics in terms of substrate consumption and growth of microbial population thus ensuring the design and process performance of various bio-reactors in practical scales. Various conventional and mathematical models have been used by researchers to investigate, control and predict treatment plant operation performance and optimizing the process at the same time (Kosińska and Miśkiewicz, 2009; Al-Zuhair et al., 2008).

The present manuscript aims to provide an overview of various effects caused due to sulfate from various sources 
along with the process biochemistry and community structure of sulfate reducing bacteria. Various factors and conditions that determine the process outcome have also been highlighted along with bioreactors used so far and the associated biokinetics of sulfate reductions.

\section{Sources and occurrence of sulfate rich wastewater}

Sulfate is one of the most abundant anions found in the environment. It is a common constituent of many natural waters and wastewaters, and is sometimes present in high concentrations. Wastewaters generated from various industrial activities such as pulp and paper industries, mining and mineral processing, production of explosives, scrubbing of flue gases, petrochemical industries, galvanic processes, battery, paint and chemical manufacturing, food processing (molasses, seafood, edible oil), and pharmaceutical industries (Lens et al., 1998) are the main source of most anthropogenic emissions. Other industrial activities involved in the production of fertilizers, dyes, glass, soaps, textiles, fungicides and leather also release high sulfate bearing effluents (Masigol et al., 2012). Certain industrial effluents may contain large concentration of sulfate (Table 1) while domestic sewage contains typically less than $500 \mathrm{mgL}^{-1}$.

In the present scenario, large quantities of sulfate are being released into the environment but very less attention has been given to its mitigation owing to its relatively low direct environmental risk compared with other pollutants. Sulfate becomes a pollutant when it is discharged into the natural environment in excess amounts leading to various environmental hazards.

Table 1. Industries producing sulfate rich wastewaters

\begin{tabular}{|c|c|c|c|}
\hline Wastewater source & $\begin{array}{c}\text { Process from which sulfate rich } \\
\text { effluent is generated }\end{array}$ & Sulfate $\left(\mathrm{mgL}^{-1}\right)$ & Reference \\
\hline Mining & & 20,800 & Bai et al. (2013) \\
\hline \multirow{2}{*}{ Tannery industry } & \multirow{2}{*}{$\begin{array}{l}\text { Deliming, pickling, tanning, retanning, } \\
\text { dyeing, greasing }\end{array}$} & $2500-3000$ & Galiana-Aleixandre et al. (2011) \\
\hline & & 3190 & Boshoff et al. (2004) \\
\hline Chemical industry & $\begin{array}{l}\text { Washing of sulfonation reaction } \\
\text { products in presence of sulfuric acid }\end{array}$ & $180,000-284000$ & Sarti and Zaiat (2011) \\
\hline Drug industry & & $500-600$ & Rao et al. (2007) \\
\hline $\begin{array}{l}\text { TNT (trinitrotoluene) } \\
\text { manufacturing process }\end{array}$ & & 5400 & Lens et al. (1998) \\
\hline Electroplating industry & & 2000 & Song et al. (1998) \\
\hline Galvanic industry & & $200-50,000$ & Tichy et al. (1998) \\
\hline Mining industry & & $100-20,000$ & Banks et al. (1997) \\
\hline Citric acid & & $2500-4500$ & Colleran et al. (1995) \\
\hline Flue gas scrubbing & & $1000-2000$ & Dijkman (1995) \\
\hline Alcohol production & & 2900 & Lens et al. (1995) \\
\hline \multirow[t]{2}{*}{ Sea food processing } & $\begin{array}{c}\text { Wastewaters originating from mussel, } \\
\text { tuna, and octopus cooking } \\
\text { manufacturing }\end{array}$ & $2100-2700$ & \multirow[t]{2}{*}{ Mendez et al. (1995) } \\
\hline & Fish-meal production wastewaters & 600 & \\
\hline Textile industry & & 2690 & Kabdasli et al. (1995) \\
\hline \multirow{2}{*}{ Pulp \& paper industry } & Thermomechanical pulping & $200-700$ & \multirow{2}{*}{ Habets \& de Vegt (1991) } \\
\hline & Chemo-thermomechanical pulping & $1200-1500$ & \\
\hline \multirow{2}{*}{ Molasses fermentation } & & $4600-6300$ & Lo et al. (1990) \\
\hline & & $2500-3450$ & Carrondo et al. (1983) \\
\hline
\end{tabular}

Excessive quantities of released sulfate can lead to pollution of the surface and ground water supplies posing health threat to life forms and therefore it needs to be treated before being discharged to maintain its level within the permissible limits (Moon et al., 2013). The upper concentration limit of sulfate in water intended for human consumption is recommended at $250 \mathrm{mgL}^{-1}$ (U.S. EPA, 1992; WHO, 1996) whereas the general standards for discharge effluents is limited upto $1000 \mathrm{mgL}^{-1}$ (MoEF, 1986). The BIS standard 10500 (BIS, 2012) states that maximum concentration of sulfate in drinking water should not exceed $200 \mathrm{mgL}^{-1}$.

\section{Effects of sulfate in the environment}

Sulfate becomes a pollutant if it is released in excess leading to various environmental hazards and impacts upon its discharge into the natural environment. It is only mildly hazardous in comparison with toxic metals and for this reason many countries have not set any guidelines for sulfate in drinking water. The presence of high sulfate in water creates bad odour, colour and taste which lead to human health problems (Pineau et al., 2008). The taste threshold of sulfate in drinking water has been fixed between 300 to $400 \mathrm{mgL}^{-1}$. However, at concentrations above $600 \mathrm{mgL}^{-1}$, sulfate can affect the taste of water and can have laxative effects (Silva et al., 2012). High concentration has been reported to cause diarrhea and dehydration in human beings (Backer, 2000). Infants are more prone to the higher sulfate concentration than adults. Hence it has been prescribed that water having sulfate more than $400 \mathrm{mgL}^{-1}$ should not be used for making infant food. Even animals are also sensitive to high levels of sulfate. 
High levels of sulfate present in the tailings (piles or dumps) from coal and some metal-bearing ores (especially those rich in pyrite and chalcopyrite) are readily oxidized by water and oxygen, resulting in acid mine drainage (AMD) creating several problems in coal and ore producing countries (Masigol et al., 2012). It has deleterious impacts on environment and many aquatic systems (Name and Sheridan, 2014; Gordon and Robinson, 1995).

Excessive quantities of released sulfate can lead to pollution of the surface and ground water supplies posing health threat to life forms and therefore it needs to be treated before being discharged to maintain its level within the permissible limits (Moon et al., 2013). In the aquatic environment, the natural sulfur cycle would be altered due to excessive release of sulfate and sulfide formed due to sulfate reduction. Sulfate ions also lead to increase in the conductivity and corrosion potential of receptor water bodies as they are one of the main contributors of mineralization of water (Silva et al., 2010). These anions promote the corrosion and scaling in pipes, structures and equipment; fouling and deposition in boilers; and acidification of soils and blockage of soil pores, retarding irrigation or water drainage systems (Bowell, 2000). Torres-Sanchez et al. (2001) observed high density and low depth pitting on the surface of stainless steel AISI 304 exposed to the action of SRB. Various other researchers have proved that the presence of SRB accelerates the process of corrosion in metals (Sun et al., 2010; Obuekwe et al., 1981).

\section{Sulfate reducing bacteria (SRB) and bacterial community structure}

Dissimilatory sulfate reduction process which utilizes sulfate ions as electron acceptors for anaerobic respiration is mediated by sulfate reducing bacteria and archaea (Widdel, 1988). So far, the known SRB can be grouped into seven phylogenetic lineages, five within the bacteria and two within the archaea based on comparative analysis of 16S rRNA sequences (Muyzer and Stams, 2008). Maximum sulfate-reducers are found within the Deltaproteobacteria ( 23 genera) which includes the typical sulfate reducer Desulfovibrio, followed by the Clostridia (Desulfotomaculum, Desulfosporosinus and Desulfosporomusa genera) which are low G+C grampositive SRB (Shen and Buick, 2004). Only thermophilic SRB occur within Nitrospirae (Thermodesulfo vibrio genus), Thermodesulfobacteria (Thermodesulfobacterium genus) and Thermodesulfobiaceae (Thermodesulfobium genus). Within the Archaea, SRB is divided into the Euryarchaeota (Archaeoglobus genus) and the Crenarchaeota (Thermocladium and Caldirvirga genera).

SRB are capable of utilizing sulfate as an electron acceptor for growth and convert it to sulfide. Sulfate reducers can be divided into two metabolic groups on the basis of their substrate utilization. The first group comprises of those species which are capable of complete oxidation of the substrates to carbon dioxide while the second group includes those which can oxidize the substrate to acetate and not completely to carbon dioxide. Representatives of the genera Desulfomonas, Desulfococcus, Desulfobacter, Desulfosarcina, Desulfotomaculum, Desulfonema, Desulfoarculus, Desulfoacinum, Desulforhabdus, Desulfomonile, as well as Desulfotomaculum acetoxidans, Desulfotomaculum sapomandens and Desulfovibrio baarsii are capable of degrading organic compounds (e.g. acetate) completely (Postgate, 1984; Tang et al., 2009; Widdel, 1988; Madigan et al., 2009) while Desulfobulbus, Desulfovibrio, Desulfomicrobium, Desulfobotulus, Desulfofustis, Desulfotomaculum, Desulfomonile, Desulfobacula, Archaeoglobus, Desulfobulbus, Desulforhopalus and Thermodesulfo bacterium are some of SRB which are not complete oxidizers (Tang et al., 2009; Madigan et al., 2009). SRB have the ability to utilize a broad range of electron donors, including lactate, propionate, acetate, and hydrogen (Widdel et al., 1992). Lactate can be consumed both by complete oxidizers as well as incomplete oxidizers, while hydrogen can be utilized more by incomplete oxidizers and very less by most complete oxidizers. The morphology, carbon source, $\mathrm{pH}$ and temperature range for growth of some SRB species which have been isolated are presented in Table 2.

\section{Biochemistry involved in sulfate reduction: formation of intermediates and end products}

The biological sulfate reduction process is mediated in dissolved oxygen deficient environment by a group of microorganisms known as sulfate reducing bacteria (SRB). Though many microbes generate $\mathrm{H}_{2} \mathrm{~S}$ metabolically, sulfate often being the primary source of $\mathrm{H}_{2} \mathrm{~S}$, the process is normally a small-scale one involving the incorporation of sulfur into cell protein and its subsequent degradation by catabolic and autolytic processes (Postgate, 1984).

$$
\mathrm{SO}_{4}^{2-}+9 \mathrm{H}^{+}+8 \mathrm{e}^{-} \rightarrow \mathrm{HS}^{-}+4 \mathrm{H}_{2} \mathrm{O} \quad \Delta G^{\circ}=+166.79 \mathrm{~kJ} \mathrm{~mol}^{-1}
$$

Under anaerobic conditions, heterotrophic sulfate reducing bacteria (SRB) use sulfate as the terminal electron acceptor for the degradation of electron donors like various organic compounds and hydrogen (Postgate, 1984). In the absence of dissolved oxygen and nitrate, sulfate is converted to sulfides by acting as a source of electron acceptor. During this process, sulfate after being activated to adenosine-phosphosulfate (APS), is reduced to sulfite, which is further reduced to sulfides as the final end products. Sulfate transport in SRB has been proposed to be driven by a proton symport, which follows chemiosmotic principles of transport. However, sulfide moves across membranes by diffusion and not by an active transport process (Cervantes et al., 2006). Once within the cytoplasm, the sulfate is reduced to sulfide in a series of reactions driven by various enzymes. The reduction of sulfate to sulfide in dissimilatory sulfate reduction is mediated by three enzymes which occur within the cell cytoplasm (Hansen, 1994) and the pathway as shown in Figure 1 is comprised of the following four steps catalyzed by membrane bound enzymes (Brunner and Bernasconi, 2005). 
Table 2. Morphology, carbon source, $\mathrm{pH}$ and temperature range for growth of some SRB species

\begin{tabular}{|c|c|c|c|c|c|}
\hline Species & Morphology and size & Carbon and energy source & pH & Temperature $\left({ }^{\circ} \mathrm{C}\right)$ & References \\
\hline Desulfovibrio aminophilus sp. & $\begin{array}{l}\text { Curved, Gram-negative, non-spore } \\
\text { forming cells }(0.2 \times 3.0-4.0 \mu \mathrm{m})\end{array}$ & $\begin{array}{l}\text { Formate, alanine, aspartate, } \\
\text { leucine, isoleucine, valine, and } \\
\text { methionine, } \mathrm{H}_{2} / \mathrm{CO}_{2} \text { and ethanol }\end{array}$ & 7.5 & 35 & Baena et al. (1998) \\
\hline Desulfotomaculum acetoxidans & & Acetate & $6.6-7.6$ & $30^{\circ} \mathrm{C}-40$ & \multirow{2}{*}{ Crine et al. (1999) } \\
\hline Desulfobacter postgatei & & Acetate & $6.2-8.4$ & $25^{\circ} \mathrm{C}-35$ & \\
\hline Desulfovibrio aerotolerans & $\begin{array}{l}\text { Curved, } 1 \times 2-5 \mu \mathrm{m}, \text { non-spore- } \\
\text { forming cells }\end{array}$ & $\begin{array}{c}\text { Lactate, pyruvate, } \mathrm{H}_{2} \text {, acetate, } \\
\text { ethanol and glycerol }\end{array}$ & 6.9 & 29 & Mogensen et al. (2005) \\
\hline Desulfotomaculum arcticum sp. & Spore-forming & Pyruvate & $7.1-7.5$ & 44 & Vandieken et al. (2006) \\
\hline Thermodesulfobacteriumhveragerdense sp.nov. & $\begin{array}{c}\text { Gram negative, rod, with an average } \\
\text { cell size of } 2.8 \times 0.5 \mu \mathrm{m} \text {, non-spore } \\
\text { forming }\end{array}$ & \multirow{2}{*}{ Lactate, pyruvate and $\mathrm{H}_{2}$} & 7.0 & $70-74$ & \multirow{2}{*}{$\begin{array}{l}\text { Sonne-Hansen and } \\
\text { Ahring (1999) }\end{array}$} \\
\hline Thermodesulfovibrio islandicus sp.nov. & $\begin{array}{c}\text { Gram negative, vibrio-shaped rod } \\
\text { with an average cell size of } \\
1.7 \times 0.4 \mu \mathrm{m} \text {, non-spore forming }\end{array}$ & & 7.0 & 65 & \\
\hline Desulfosporosinus acidiphilus & $\begin{array}{c}\text { Gram negative, non-motile, curved } \\
\text { rods, } 4-7 \times 0.8-1.0 \mu \mathrm{m}\end{array}$ & $\begin{array}{c}\mathrm{H}_{2} \text {, lactate, pyruvate, glycerol, } \\
\text { glucose, and fructose }\end{array}$ & 5.2 & 35 & Alazard et al. (2010) \\
\hline Desulfofabagelida sp. & Gram-negative, 3.1×5.4-6.2 $\mu \mathrm{m}$ & $\begin{array}{l}\text { Acetate, propionate, butyrate, } \\
\text { lactate and hydrogen, }\end{array}$ & 7.1-7.6 & 7 & Knoblauch et al. (1999) \\
\hline
\end{tabular}




\section{Step 1: Transfer of sulfate inside the bacterial cell}

Step 2: Activation of internal sulfate to adenosine $5^{\prime}$ phosphosulfate (APS) with adenosine triphosphate (ATP) mediated by enzyme ATP sulfurylase.

Step 3: Reduction of APS to sulfite by APS reductase

Step 4: Finally reduction of sulfite to sulfide by sulfite reductase

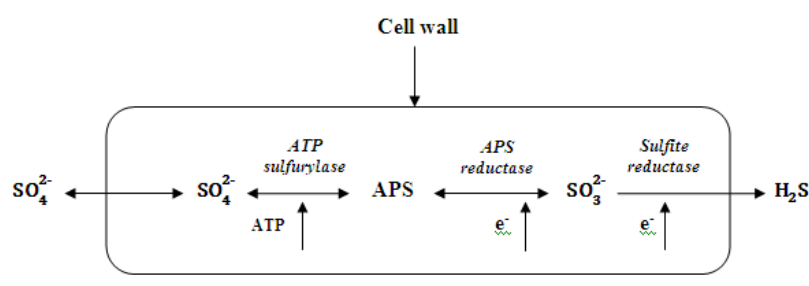

Figure 1. Pathway of dissimilatory sulfate reduction (Shen and Buick, 2004)

The similarity between assimilatory and dissimilatory sulfate reduction lies in the presence of enzyme ATP sulfurylase, which leads to formation of APS, mediated by enzyme APS reductase for formation of sulfite. The main difference lies in the reversible transition from external sulfate to sulfite in dissimilatory sulfate reduction as compared to assimilatory sulfate reduction. Sulfite has been conceived to be an intermediate of sulfate reduction in sulfate reducing bacteria like Desulfovibrio., $s p$, as well as in other microorganisms and higher plants (Ishimoto and Yagi, 1961). So far two mechanisms have been proposed to describe the reduction of sulfite to sulfide: (i) by direct reduction of sulfite to sulfide without the formation of any intermediate compound and (ii) through the formation of trithionate and thiosulfate as proposed by Kobayashi et al. (1969). With the reduction of six electrons, the direct reduction of sulfite to sulfide takes place leading to the formation of sulfide through a single step only and is catalyzed by sulfite reductase enzyme (Fukui and Takii, 1994). In the reduction of sulfite to sulfide through the trithionate pathway (Shen and Buick, 2004), the first step involves the reduction of sulfite to trithionate catalyzed by trithionate reductase with the reduction of two electrons. In the second step trithionate is converted to thiosulfate with the reduction of two electrons in the presence of enzyme thiosulfate reductase. In the final step sulfide is formed from thiosulfate with release of again two electrons.

Trudinger and Loughlin (1981) reported that trithionate and thiosulfate formation can take place by chemical reactions in the culture medium with high sulfite concentrations or abiotically by reaction between sulfite and sulfide (Widdel, 1992) and that neither trithionate nor thiosulfate are obligatory intermediates in the sulfite reduction pathway. However, formation of thiosulfate (Fitz and Cypionka, 1990) and trithionate (Kobayashi et al.,
1969) as intermediates in the reduction of sulfite by Desulfovibrio vulgaris has been reported. Findley and Akagi (1970) have even provided evidence about the generation of both sulfur atoms of thiosulfate from sulfite and, also reduction of the outer sulfur atom to sulfide and regeneration of the inner sulfur atom back to sulfite during thiosulfate reduction. Trithionate and thiosulfate formation as intermediates with whole cells of sulfate reducing bacterium Desulfovibrio desulfuricans supports the trithionate pathway of sulfite reduction (Fitz and Cypionka, 1990). Thus the trithionate pathway of sulfite reduction may be a fully functional biochemical process (Shen and Buick, 2004).

\section{Treatment of sulfate rich wastewater}

Normally sulfate containing wastewaters can be treated using physicochemical and biological methods. However, biological treatment is preferred due to the overlying limitations of separation and appropriate disposal of the solid phase, relatively high cost and energy consumption involved in physicochemical methods (Silva et al., 2002). Biologically, sulfate bearing wastewater is generally treated by anaerobic processes (Dries et al., 1998; Fang, 1997; Percheron et al., 1997). There are several factors that affect biological sulfate degradation efficiency and formation of end products.

\subsection{Factors influencing sulfate reduction}

\subsection{1. $p H$}

Sheoran et al. (2010) reported that SRB has two threshold inhibition levels, one for the undissociated sulfide $\left(\mathrm{H}_{2} \mathrm{~S}\right)$ and the other for the total sulfide. The state of sulfide solely depends on the $\mathrm{pH}$ of the environment as shown in Figure 2. Most of the SRB's are reported to be neutrophilic (Widdel, 1988) and prefer an environment having $\mathrm{pH}$ between 7.5-8. However various acid tolerant species have also been seen to thrive for sulfate reduction at $\mathrm{pH}$ as low as 3.8 (Kimura et al., 2006), while some species have been found to be alkaliphilic and the highest $\mathrm{pH}$ seen to support the growth of SRB's has been reported to be 10 (Pikuta et al., 2003). Below pH 5, activity of SRB's is reduced considerably whereas at neutral $\mathrm{pH}$ their activity is enhanced. The inactivity of SRB's at low pH is mainly attributed to the acidification of the cytoplasm which inhibits the formation of a proton motive force. At a $\mathrm{pH}$ less than 7.2, un-dissociated $\mathrm{H}_{2} \mathrm{~S}$ is dominant and reaches the threshold limit while at a $\mathrm{pH}$ above 7.2, the total sulfide is responsible for the inhibitory effect (Perry et al., 1984). At $\mathrm{pH}$ of 8.5 , the $\mathrm{HS}^{-}$further dissociates into the sulfide dianion $\left(\mathrm{S}^{2-}\right)$ form and becomes the predominant sole species at $\mathrm{pH}$ value above 10 (Tang et al., 2009; Visser, 1995). The SRB are less sensitive to total sulfide when the $\mathrm{pH}$ is increased from 6.8 to 8.0 and more sensitive to the undissociated sulfide concentration. At low $\mathrm{pH}$ the produced hydrogen sulfide exists in undissociated form and as the $\mathrm{pH}$ increases it dissociates into $\mathrm{HS}^{-}$and $\mathrm{S}^{2-}$. 


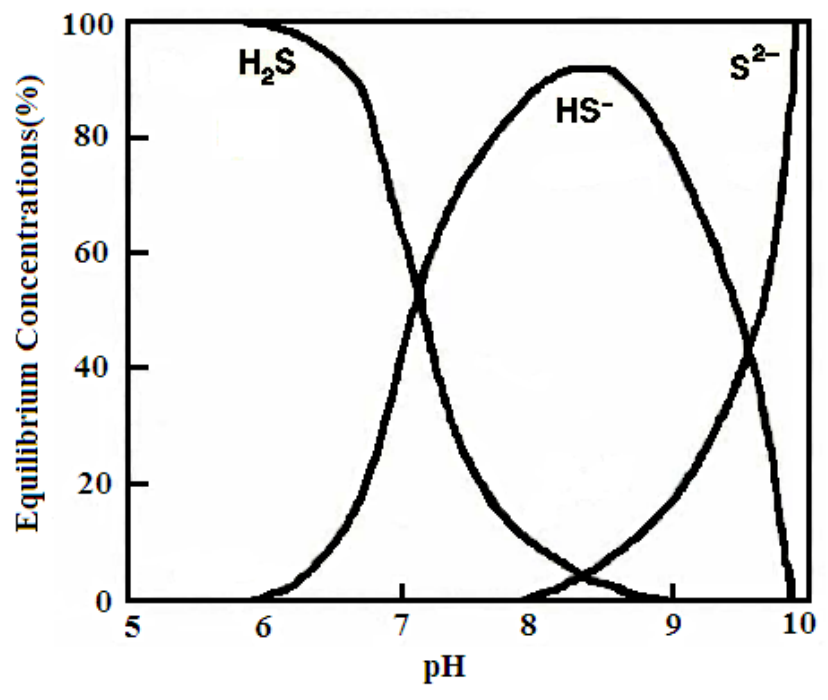

Figure 2. Prevalent forms of sulfide at different $\mathrm{pH}$ values (Lens et al., 1998)

Most sulfidogenic bioreactors have been operated around neutral $\mathrm{pH}$.In order for SRB to survive, a $\mathrm{pH}$ in the range of $5-8$ is required (Willow and Cohen, 2003) while outside this range, the rate of microbial sulfate reduction generally declines. Low $\mathrm{pH}(<5)$ normally inhibits sulfate reduction and increases the solubility of metal sulfides (Dvorak et al., 1992). Below a pH of 4, bioreactors have been less successful. However, Elliott et al. (1998) reported the presence of SRB activity at a $\mathrm{pH}$ of 3.0 in an anaerobic upflow bioreactor. Kolmert and Johnson (2001) reported the growth of a mixed acidophilic SRB culture in a medium with a $\mathrm{pH}$ of 3.0 thus supporting the view by Postgate (Postgate, 1984) that mixed SRB cultures are more tolerant to extreme conditions than pure cultures. Sulfate reduction has also been reported to occur at a $\mathrm{pH}$ of 10 (Pikuta et al., 2003). However, significant reduction rates have been shown until a $\mathrm{pH}$ of 8.0 where a volumetric activity of $25 \mathrm{SO}_{4}{ }^{2-} \mathrm{g} \mathrm{Ld}^{-1}$ was reported (van Houten et al., 1995).

\subsubsection{Electron donors/carbon source}

Lens et al. (1998) reported the diversity of SRB in their carbon source utilization and the metabolic activities. The carbon and energy source provides the energy for the growth and maintenance of SRB based on the reaction given below:

$$
\mathrm{SO}_{4}^{2-}+4 \mathrm{H}_{2} \mathrm{O}+8 \mathrm{e}^{-} \rightarrow \mathrm{S}^{2-}+8 \mathrm{OH}^{-}
$$

The electrons required for the sulfate reduction are generated by the oxidation of a carbon source (e.g, lactate, acetate, and propionate).

The ATP produced, using the energy released from oxidation of the organic carbon is utilized for the reduction of sulfate to sulfide. In most instances, the electron donor and the carbon source are the same compound. Only when hydrogen is used as the electron donor, $\mathrm{CO}_{2}$ is used as the carbon source. A minimum $\mathrm{COD} / \mathrm{SO}_{4}{ }^{2-}$ mole ratio of 0.67 is required for achieving theoretically possible removal of sulfate (Choi and Rim, 1991). Various organic compounds such as sewage sludge, leaf mulch, molasses animal and manure have been used as carbon sources in addition to the low molecular weight organic compounds. Some of the commonly used electron donors are hydrogen, formate, methanol, ethanol, molasses, lactate, acetate, propionate and butyrate, sugar, hydrocarbons and organic waste (Liamleam and Annachhatre, 2007). Table 3 shows the advantages and disadvantages of different carbon sources.

Table 3. Electron donors and carbon sources for SRB (Liamleam and Annachhatre, 2007)

\begin{tabular}{|c|c|c|}
\hline Carbon Source & Advantage(s) & Disadvantage(s) \\
\hline Hydrogen & $\begin{array}{l}\text { More efficient utilization by SRB } \\
\text { than methanogens }\end{array}$ & $\begin{array}{c}\text { Only a few anaerobes can grow with hydrogen as sole } \\
\text { energy source }\end{array}$ \\
\hline Acetate & - & $\begin{array}{l}\text { SRB cannot completely oxidize acetate even with excess } \\
\text { sulfate levels }\end{array}$ \\
\hline Methanol & $\begin{array}{l}\text { Readily available and cost } \\
\text { effective }\end{array}$ & Low growth rate of SRB \\
\hline Ethanol & $\mathrm{SO}_{4}{ }^{2-}$ conversion efficiency & Slow growth rate of SRB, produces acetate \\
\hline Molasses & Low cost, readily available & $\begin{array}{c}\text { Accumulation of non-biodegradable content reduces } \\
\text { biomass activity and COD removal. } \\
\text { High VFA generation }\end{array}$ \\
\hline Lactate & Most SRB can utilize it & $\begin{array}{l}\text { Complete lactate oxidation not achieved by some SRB } \\
\text { species }\end{array}$ \\
\hline Sugar & $\begin{array}{l}\text { Easily degraded under anaerobic } \\
\text { conditions. }\end{array}$ & Costly \\
\hline Hydrocarbons & - & $\begin{array}{l}\text { Free energy change low as estimated for the methane } \\
\text { oxidation }\end{array}$ \\
\hline $\begin{array}{l}\text { Organic waste (sewage sludge, } \\
\text { animal manure, leaf mulch, wood } \\
\text { chips, sawdust, cellulose.) }\end{array}$ & Cost effective. & Very less utilization rate \\
\hline
\end{tabular}




\subsection{3. $\mathrm{COD} / \mathrm{SO}_{4}{ }^{2-}$ ratio}

$\mathrm{COD} / \mathrm{SO}_{4}{ }^{2-}$ ratio appears to be a key factor in the regulation of sulfate reduction as it determines the competition between SRBs and methanogenic bacteria (MB) for monomeric (e.g sugar, amino acids) and $\mathrm{H}_{2}$ or acetate compounds (Sarti et al., 2009). In addition, $\mathrm{COD} / \mathrm{SO}_{4}{ }^{2-}$ also determines the electron flow during sulfate reduction and methanogenesis. It has been reported theoretically that conversion of $1 \mathrm{~mol}$ of sulfate requires $0.67 \mathrm{~mol}$ of COD or electron donor (Choi and Rim, 1991; Omil et al., 1998). When this ratio is decreased i.e there is more sulfate available, then the amount of organic matter required by the biomass for sulfate reduction is not present and its then that an addition of an external source of organic matter, preferably carbon source/electron donor is required. Conversely the sulfate reduction is also hampered when this ratio is increased as the electron transport to the sulfate reducing bacteria decreases. In fact, when the ratio increases beyond a certain value, there is competition between methane formers and sulfate reducers for acetate. Choi and Rim (1991) indicated that sulfate reducers and methane formers are very competitive at a ratio of 1.7 to 2.7 and observed that methane producers dominate at higher ratio while sulfate reducers dominate at lower ratios. Chou et al. (2008) studied the competition reaction kinetics of SRB and $\mathrm{MB}$ at different $\mathrm{COD} / \mathrm{SO}_{4}{ }^{2-}$ ratios by finding out the values of mass fraction of SRB and MB i.e $f(S R B)$ and $f(M B)$ respectively. They found out that $f(S R B)$ continued to be higher up-to a $\mathrm{COD} / \mathrm{SO}_{4}{ }^{2-}$ of 1.3 indicating that SRB could outcompete MB for bacterial growth. However, as the ratio was increased upto 2 and 3, the mass fraction of $\mathrm{MB}$ became more than mass fraction of SRB's. The following Table 4 shows various studies carried out at different $\mathrm{COD} / \mathrm{SO}_{4}{ }^{2-}$ ratio along with the sulfate and organic matter removal efficiencies.

Table 4. Sulfate and COD removal at different $\mathrm{COD} / \mathrm{SO}_{4}{ }^{2-}$ ratio

\begin{tabular}{|c|c|c|c|c|}
\hline Reactor type & $\mathrm{COD} / \mathrm{SO}_{4}{ }^{2-}$ & $\begin{array}{c}\text { COD removal } \\
\text { efficiency }\end{array}$ & $\mathrm{SO}_{4}{ }^{2-}$ removal efficiency & Reference \\
\hline SBBR & $1-1.5$ & $48-95$ & $84-98$ & Archilha et al. (2010) \\
\hline$A B R$ & 6 & $>85$ & 96.8 & $\begin{array}{l}\text { Vossoughi et al. } \\
\text { (2003) }\end{array}$ \\
\hline UASB & $0.67-1.5$ & 100 & 94 & Velasco et al. (2008) \\
\hline Batch & 2.6 & 92.6 & $>92$ & Cao et al. (2011) \\
\hline EGSB & 6 & $>65$ & $>85$ & de Smul et al. (1999) \\
\hline FBR & 1.17 & 87 & 91 & Thabet et al. (2009) \\
\hline SBBR & $3.67 \pm 0.19$ & 32 & 99 & Sarti and Zaiat (2011) \\
\hline UASB & 1 & 67.4 & 85.6 & $\begin{array}{c}\text { Rodriguez et al. } \\
\text { (2012) }\end{array}$ \\
\hline UASB & 6.67 & - & $>95$ & Sipma et al. (1999) \\
\hline CSTR & 1.2 & $99 \pm 0.6$ & $86 \pm 0.5$ & Oyekola et al. (2010) \\
\hline CSTR & 2 & N.A & 99 & Zhao et al. (2010) \\
\hline Upflow hybrid reactor & 1.3 & $>90$ & $>90$ & \multirow{2}{*}{ Sabumon (2008) } \\
\hline Batch & 0.7 & $>85$ & $>90$ & \\
\hline Batch & 1.6 & N.A & 97.4 & \multirow{2}{*}{ Wang et al. (2008) } \\
\hline Continuous & 2.7 & N.A & $>94.6$ & \\
\hline
\end{tabular}

SBBR: Sequential batch biofilm reactor; UASB: Upflow anaerobic sludge blanket reactor; FBR: Fixed bed reactor; EGSB: Expanded granular sludge bed reactor; ABR: Anaerobic baffled reactor; CSTR: Continuous stirred tank reactor

\subsubsection{Temperature}

Sulfate reducers can grow over a wide range of temperature. Some can thrive at temperature as low as $5^{\circ} \mathrm{C}$ (Sahinkaya, 2009) while others have been reported to grow at temperature above $50^{\circ} \mathrm{C}$ (Rosnes et al., 1991; Lopes et al., 2007). Sulfate reducing bacteria can be classified into mesophiles (growth temperature $<40^{\circ} \mathrm{C}$ ), moderate thermophiles (growth temperature $40-60^{\circ} \mathrm{C}$ ) and extreme thermophiles $\left(>60^{\circ} \mathrm{C}\right)$. But most of the studies conducted so far in laboratory scale for sulfate reduction show that majority of the sulfate reducers such as Desulfobacter hydrogenophilus, Desulfobacter curvatus, Desulfovibrio latus, Desulfovibrio vibrioformis and Desulfovibrio halotolerans are mesophilic in nature. Arrhenius plot has been employed in order to gain an insight of the adaptation of bacteria for sulfate reduction in low temperature regions like marshy areas, deep sea, sediments etc.

Ingvorsen et al. (2003) investigated the effect of temperature on sulfate reduction on concentrated sludge and native sludge. They found out that the exponential phase was attained after $6 \mathrm{hr}$ when temperature was $20^{\circ} \mathrm{C}$ as against $20 \mathrm{hr}$ when temperature was $5^{\circ} \mathrm{C}$. Various studies by Pallud \& Cappellen (2006) and Sawicka et al. (2012) on samples obtained from marshes and sediments show that the sulfate reduction rates increase with increase of temperature values of $20-30^{\circ} \mathrm{C}$. The $E_{a}$ and $Q_{10}$ values found in the studies showed that the temperature range of $20-30^{\circ} \mathrm{C}$ is optimum for sulfate reduction. de Smul et al. (1999) found that the optimum sulfate reduction rate were maintained at a temperature of $33^{\circ} \mathrm{C}$ 
with the expanded sludge granular bed (ESGB) reactors fed with ethanol and ethylene glycol. In addition to that, they also observed the suppression of overall sulfidogenic activity in contrast to methanogenesis which became active once the temperature was increased to $55^{\circ} \mathrm{C}$. Similar results were also found by Sulaiman Al-Zuhair et al. (2008) and Moosa et al. (2002) where fastest drop in sulfate concentration was observed at temperature of $35^{\circ} \mathrm{C}$. Studies by Moosa et al. (2005) on anaerobic sulfate reduction across a temperature of $20-35^{\circ} \mathrm{C}$ observed that the values of bio-kinetic parameters namely specific growth rate $\left(\mu_{\mathrm{m}}\right)$ and yield $(\mathrm{Y})$ did not change with temperature while Ks declined to a value of 0.949 from $0.016 \mathrm{~kg}$ dry weight $\mathrm{m}^{-3}$ and $\mathrm{k}_{\mathrm{d}}$ value increased from 0.008 to 0.038 per hour.

\subsubsection{Sulfide}

The toxicity of sulfide is regarded as being $\mathrm{pH}$ dependent because in the $\mathrm{pH}$ range of 6-8, sulfide exists as a mixture of $\mathrm{HS}^{-}$and $\mathrm{H}_{2} \mathrm{~S}$. Undissociated hydrogen sulfide $\left(\mathrm{H}_{2} \mathrm{~S}\right)$ becomes the dominant sulfide species at $\mathrm{pH}$ lower than 6 (Moosa and Harrison, 2006). The chemical reactions taking place for the sulfide species is governed by the equations given below:-

$$
\begin{aligned}
& \mathrm{H}_{2} \mathrm{~S} \rightarrow \mathrm{HS}^{-}+\mathrm{H}^{+} \\
& \mathrm{HS}^{-} \rightarrow \mathrm{S}^{2-}+\mathrm{H}^{+}
\end{aligned}
$$

The total Hydrogen sulfide is found out as below

$$
\mathrm{H}_{2} \mathrm{~S}_{\text {total }}=\mathrm{H}_{2} \mathrm{~S}_{\text {aq. }}+\mathrm{HS}^{-}
$$

Two theories have been postulated so far for sulfide inhibition. The first one states that the undissociated sulfide molecule can pass through the cell membrane, making the cell inactive by destroying the bacterial proteins (Postgate, 1984; Speece, 1983) and interfering with the metabolic coenzymes by formation of sulfide bond (Parkin and Owen, 1986). The other one is applicable when there are heavy metals in the system, which states that due to the precipitation of heavy metals the sulfate reducing bacteria are deprived of the essential trace nutrients used as cofactors and hence their growth gets inhibited (Bharathi et al., 1990). However it was seen that the sulfide toxicity is reversible and the normal cell growth and sulfate reduction rates are attained as soon as sulfide is removed from the system (Okabe et al., 1995; Krishnanand and Parkin, 1996). Table 5 depicts the effects of sulfide on the sulfate reducing bacteria at different

\begin{tabular}{|c|c|c|c|c|}
\hline \multirow[b]{2}{*}{ Organism } & \multirow[b]{2}{*}{ Reactor } & \multicolumn{2}{|c|}{ Sulfide inhibition level $\left(\mathrm{mgL}^{-1}\right)$} & \multirow[b]{2}{*}{ Reference } \\
\hline & & $\begin{array}{c}\text { Un-dissociated sulfide } \\
\left(\mathrm{mgL}^{-1}\right)\end{array}$ & $\begin{array}{c}\text { Dissolved sulfide } \\
\left(\mathrm{mgL}^{-1}\right)\end{array}$ & \\
\hline \multirow{2}{*}{ Mixed culture } & \multirow{2}{*}{ CSTR } & 290 & --- & \multirow{2}{*}{$\begin{array}{c}\text { Moosa and Harrison } \\
(2006)\end{array}$} \\
\hline & & --- & 1000 & \\
\hline Mixed culture & Continuous & --- & 1000 & $\begin{array}{c}\text { Icgen and Harrison } \\
\text { (2006) }\end{array}$ \\
\hline Wet granular sludge & UASB & --- & 100 & Lopes et al. (2010) \\
\hline \multirow{2}{*}{$\begin{array}{l}\text { Desulfovibrio } \\
\text { Desulfuricans }\end{array}$} & Batch culture & --- & 251 & \multirow[b]{2}{*}{ Okabe et al. (1995) } \\
\hline & $\begin{array}{l}\text { Continuous } \\
\text { chemostat }\end{array}$ & --- & 250 & \\
\hline Mixed culture & $\begin{array}{l}\text { Ethanol-lactate } \\
\text { fed FBR }\end{array}$ & --- & 613.44 & $\begin{array}{l}\text { Nevatalo et al. } \\
\text { (2010) }\end{array}$ \\
\hline $\begin{array}{l}\text { Desulfovibrio } \\
\text { Desulfuricans }\end{array}$ & $\begin{array}{l}\text { Bacterial } \\
\text { culture }\end{array}$ & & 34.08 & Truong et al. (2013) \\
\hline $\begin{array}{l}\text { Desulfovibrio } \\
\text { Desulfuricans }\end{array}$ & Chemostat & --- & $212 \pm 23$ & Okabe et al. (1992) \\
\hline Granular Sludge & UASB & --- & 115 & Lopes et al. (2007) \\
\hline SRB growing on lactate and sulfate & --- & --- & 547 & Reis et al. (1992) \\
\hline Mixed culture & Chemostat & --- & $150-200$ & $\begin{array}{c}\text { Krishnanand and } \\
\text { Parkin (1996) }\end{array}$ \\
\hline AMD treatment sludge & Serum vials & 302.6 & 1781 & $\begin{array}{l}\text { O'Flaherty et al. } \\
\text { (1998) }\end{array}$ \\
\hline Anaerobic hybrid reactor sludge & $\begin{array}{l}\text { Packed up-flow } \\
\text { hybrid reactor }\end{array}$ & 258.4 & 2736.5 & $\begin{array}{l}\text { O'Flaherty and } \\
\text { Colleran (1999) }\end{array}$ \\
\hline
\end{tabular}
concentration levels studied so far.

Table 5. Toxicity levels of sulfide in Sulfate reducing bacteria

\subsubsection{Heavy metals}

The capacity of various heavy metals to react with the functional groups of enzymes and deactivating them in the process results in toxic effects on microorganisms including SRB which are generally utilized in bioremediation process. The heavy metals are even capable of substituting essential ions on cellular sites causing denaturation of proteins (Cabrera et al., 2006). The main criteria on which the removal ability of the SRB 
depends, is the metal concentration in solution which may lead to decrease in metabolic activity of the bacteria or even death when the metal concentration is very high. The toxicity concentrations of heavy metals for SRB have been reported to range from a few $\mathrm{mgL}^{-1}$ to as high as 100 $\mathrm{mgL}^{-1}$ (Sani et al., 2001). Martins et al. (2009) reported that the variation of the metal species also plays a very important role imparting toxicity to the SRB. For instance, the less mobile arsenate $\mathrm{As}(\mathrm{V})$ is more toxic than arsenite $\mathrm{As}(\mathrm{III})$, while inorganic species are more toxic as compared to their methylated counterparts (Turpeinen et al., 1999). Various resistance mechanisms such as sequestration or transformation to other chemical species have been observed in different organisms as a means of tolerance to the toxic effects exhibited by various metal ions (Valls and Lorenzo, 2002). Jong and Parry (2003) reported the decrease in sulfate reduction with increasing initial concentrations of metals which might be attributed to firstly to reduction in metabolic activity of SRB due to metal toxicity. The second reason could be the partial blockage of the sand-bed of the reactor leading to severe mass transfer limitations which are common at higher metal concentrations. The toxic concentrations of some heavy metals as reported by Hao et al. (1994) employing a mixed culture of SRB for studying the effects of heavy metals on sulfate reduction are $\mathrm{Zn}\left(25-40 \mathrm{mgL}^{-1}\right), \mathrm{Pb}$ $\left(75-80 \mathrm{mgL}^{-1}\right), \mathrm{Cu}\left(4-20 \mathrm{mgL}^{-1}\right), \mathrm{Cd}\left(>4-20 \mathrm{mgL}^{-1}\right), \mathrm{Ni}$ (10-20 mgL $\left.\mathrm{mg}^{-1}\right)$ and $\mathrm{Cr}\left(60 \mathrm{mgL}^{-1}\right)$. The sulfate removal IC50 (concentration causing $50 \%$ inhibition of SRB sulfate removal efficiency) for Cu was reported to be $156 \mathrm{mgL}^{-1}$ (Song et al., 1998) in contrast to $1.02 \mathrm{mgL}^{-1}$ as reported by Sani et al. (2001) who used D. desulfuricans strain along with a specific metal toxicity medium containing constituents that did not result in any abiotic precipitation of metal ions. Important studies on toxicity levels of various metals have been listed in Table 6 . This comparative difference shows that the chemical and physicochemical properties of the environment surrounding the SRB play an important role in determining the level of metal toxicity and inhibition in SRB (Jong and Parry, 2003). In the studies conducted by Martins et al. (2009), the inhibition of sulfate reducing ability of the SRB was significant in the presence of zinc concentration of $150 \mathrm{mgL}^{-1}$ and copper concentration of $80 \mathrm{mgL}^{-1}$.

Table 6. Toxicity levels of various metals

\begin{tabular}{|c|c|c|c|}
\hline Metal & SRB & Toxic concentration $\left(\mathrm{mgL}^{-1}\right)$ & Reference \\
\hline \multirow{4}{*}{ Zinc } & Mixed culture & 150 & Martins et al. (2009) \\
\hline & Mixed culture & $25-40$ & Hao et al. (1994) \\
\hline & Desulfovibrio vulgaris & 20 & Cabrera et al. (2006) \\
\hline & Desulfomicrobium sp. & $>125$ & Azabou et al. (2007) \\
\hline \multirow{5}{*}{ Copper } & Mixed culture & 80 & Martins et al. (2009) \\
\hline & Mixed culture & $4-20$ & Hao et al. (1994) \\
\hline & Desulfovibrio vulgaris and Desulfovibrio sp. & 9 & Cabrera et al. (2006) \\
\hline & Desulfovibrio desulfuricans G20 & 2 & Sani et al. (2001) \\
\hline & Desulfomicrobium sp. & $>10$ & Azabou et al. (2007) \\
\hline Lead & Mixed culture & $75-80$ & Hao et al. (1994) \\
\hline Iron & Desulfomicrobium sp. & $>60$ & Azabou et al. (2007) \\
\hline \multirow{2}{*}{ Chromium } & Mixed culture & 60 & Hao et al. (1994) \\
\hline & Desulfovibrio vulgaris and Desulfovibrio sp. & $>15$ & Cabrera et al. (2006) \\
\hline \multirow{2}{*}{ Nickel } & Mixed culture & $10-20$ & Hao et al. (1994) \\
\hline & Desulfovibrio vulgaris and Desulfovibrio sp. & $>8.5$ & Cabrera et al. (2006) \\
\hline Cadmium & Mixed culture & $4-20$ & Hao et al. (1994) \\
\hline Manganese & Desulfovibrio vulgaris and Desulfovibrio sp. & $>10$ & Cabrera et al. (2006) \\
\hline
\end{tabular}

\subsection{Anaerobic bioreactors for sulfate reduction}

\subsubsection{Batch/semi-batch/sequential bioreactors}

Batch reactor using anaerobic reactors and serum vials as a process is based on the scientific assumption that biodegradation of various pollutants can be achieved by periodic exposure of the microorganisms to defined processes and conditions. Important parameters such as time and frequency of exposure of microorganisms to different pollutant concentration can be set irrespective of any inflow conditions. It offers many advantages over other continuous reactors in terms of flexibility of operation such as operation even at low retention time, control over microbial population and operation with variety of reactor designs. Sequential batch reactor and sequencing batch biofilm reactor are the most common configuration of batch reactors used for sulfate removal. These reactors offers specific conditions for operating the system at high cellular retention times once it promotes microbial immobilization or cellular adhesion in some inert support such as porcelain rings (Mohan et al., 2005), mineral coal (Sarti et al., 2010), and polyurethane foam (Archilha et al., 2010). The operation of such reactor comprises of feeding liquid influent, anaerobic biological reactions, settling of sludge, decantation and then drawing the final effluent (Dague, 1993). Some batch reactors used in sulfate removal process are listed in Table 7. 
Table 7. Performance of various batch reactors in sulfate removal

\begin{tabular}{|c|c|c|c|c|c|c|c|c|}
\hline Batch reactor & Substrate & Microbial culture & $\begin{array}{c}\text { Sulfate loading rate } \\
\left(\mathrm{gL}^{-1} \mathrm{~h}^{-1}\right) / \text { Inflow } \\
\text { concentration }\left(\mathrm{gL}^{-1}\right)^{*}\end{array}$ & $\begin{array}{l}\text { Reduction rate/\% } \\
\text { reduction* }\end{array}$ & Temperature & $\mathrm{pH}$ & HRT (h) & Reference \\
\hline $\begin{array}{l}500 \mathrm{ml} \text { Erlenmeyer } \\
\text { flask }\end{array}$ & lactate & $\begin{array}{c}\text { Desulfovibrio } \\
\text { desulfuricans ATCC } \\
5575\end{array}$ & $0.8^{*}$ & --- & 35 & 7 & 10 & Okabe et al. (1995) \\
\hline An SBR & Butanol & Mixed culture & 0.02 & 0.017 & $25 \pm 1$ & $5.9-6.5$ & 48 & Sarti and Zaiat (2011) \\
\hline ASBBR & Ethanol & Mixed culture & 0.041 & 0.035 & $31 \pm 2$ & --- & 48 & Sarti et al. (2010) \\
\hline An SBBR & Sodium lactate & Mixed culture & $1.6^{*}$ & $82^{*}$ & $30 \pm 2$ & $7.2-8.4$ & 24 & Mohan et al. (2005) \\
\hline Anaerobic reactors & Sucrose & Mixed culture & $1.2^{*}$ & $>90 *$ & $35 \pm 1$ & $6-6.5$ & 8 & Mizuno et al. (1998) \\
\hline ASBR & $\begin{array}{c}\text { Sucrose, starch, } \\
\text { meat extract, } \\
\text { soybean oil } \\
\end{array}$ & Mixed culture & 1.5 & 1.33 & 30 & $8 \pm 0.1$ & 19.16 & Costabile et al. (2011) \\
\hline ASBR (fed batch) & -do- & -do- & 4.5 & 3.88 & -do- & $7.9 \pm 0.2$ & - & \\
\hline $\begin{array}{l}\text { Glass reaction } \\
\text { flasks }\end{array}$ & $\begin{array}{l}\text { Maple wood chips, } \\
\text { Maple sawdust, } \\
\text { Composted poultry } \\
\text { manure, Leaf } \\
\text { compost }\end{array}$ & $\begin{array}{c}\text { Anaerobically digested } \\
\text { sludge }\end{array}$ & $5.5^{*}$ & $99 *$ & $22 \pm 1$ & $5.45-5.51$ & $192-384$ & $\begin{array}{l}\text { Neculita and Zagury } \\
\qquad(2008)\end{array}$ \\
\hline SBR & $\begin{array}{c}\text { Sodium lactate and } \\
\text { lactic acid }\end{array}$ & Granular sludge & $1.2^{*}$ & $100 *$ & 30 & 7 & 5 & $\begin{array}{l}\text { Torner-Morales and } \\
\text { Buitrón (2010) }\end{array}$ \\
\hline $\begin{array}{l}1 \mathrm{~L} \mathrm{cylinder} \mathrm{Semi} \\
\text { batch reactor }\end{array}$ & Silage & Mixed culture & $>1$ & 0.034 & 30 & 5.5 & $20-40$ & Wakeman et al. (2010) \\
\hline
\end{tabular}




\subsubsection{Flow through bioreactors}

Different flow through bioreactor configurations have been reported in literature for anaerobic reduction of sulfate. Some of the common bioreactor configurations include continuous stirred tank reactors (Moosa et al., 2002, 2005; Herrera et al., 1997); membrane reactors (Chuichulcherm et al., 2001); packed bed reactors (Jong and Parry, 2003; Chang et al., 2000; Brahmacharimayum and Ghosh, 2014); and up-flow anaerobic sludge blanket reactors (Colleran et al., 1994; Sanchez et al., 1997). These bioreactors can be classified into two main groups based on the mixing regime of the influent (Kaksonen, 2004). The bioreactors with completely mixed regime can be subdivided into CSTR and MBR based on the biomass retention characteristic of the reactor. Biomass retention increases biomass concentrations, which is especially important in sulfidogenic bioreactors because of the low growth rate of anaerobic microorganisms. In case of incompletely mixed or gradient type bioreactor, the bioreactor can be categorized into PBR and UASB based on the use or non-use of the carrier material, respectively. These reactors with gradient mixing regime are mainly used for soluble, low suspended solid wastes (Jhung and Choi, 1995). In case of these bioreactors, the activity of the bioreactor is determined by the activity of the biomass and the biomass concentration.

\subsubsection{Continuous stirred tank reactors (CSTR)}

In this reactor, mixing is done by a mechanical stirrer resulting in a completely mixed system. However, CSTRs are subjected to washout of biomass (Speece, 1983). Biomass retention has been enhanced by employing sedimentation systems and cationic flocculants (White et al., 1995). The performance of CSTR in treating sulfate rich wastewaters with different substrate and under varying volumetric loading rates has been investigated by various researchers (Table 8). Moosa et al. (2002) investigated the effects of initial sulfate concentration and its volumetric loading on the kinetics of reaction and activity of sulfatereducing bacteria. The increase in initial concentration of sulfate in the range $1.0-10.0 \mathrm{~kg} \mathrm{~m}^{-3}$ enhanced the reaction rate from $0.007-0.17 \mathrm{~kg} \mathrm{~m}^{-3} \mathrm{~h}^{-1}$.

\subsubsection{Membrane bioreactors (MBR)}

It is the combination of a membrane process with a suspended growth reactor and is relatively new in the field of sulfate reduction. The advantage of this configuration is that almost complete biomass retention can be obtained which is especially useful in slow growing processes (Bijmans, 2008). Membrane bioreactors commonly adopt a biomass retention system relying on the difference in density between the sludge and the reactor liquor, resulting in settling or floatation of the sludge. Vallero et al. (2005) investigated the sulfate reducing potential of anaerobic membrane reactor in salt rich wastewaters using a $6 \mathrm{~L}$ submerged anaerobic membrane bioreactor (SAMBaR) inoculated solely with Desulfobacter halotolerans (Table 5). A sulfate reduction rate up to $6.6 \mathrm{~g} \mathrm{SO}_{4}{ }^{2-} \mathrm{L}^{-1} \mathrm{~d}^{-1}$ was achieved in the SAMBaR at an HRT of $9 \mathrm{~h}$ including the backflow of permeate used for back flushing. Mizuno et al. (1998) investigated the biological sulfate removal in the acidogenic bioreactor with an ultra-filtration membrane system at $35^{\circ} \mathrm{C}$ using sucrose as the sole organic substrate. The efficiency of sulfate removal by sulfate reduction reached about $100 \%$ in the membrane bioreactor, and 55 to $87 \%$ of sulfide was removed from the permeate by membrane filtration.

\subsubsection{Upflow anaerobic sludge blanket reactor (UASB)}

The UASB reactor was developed for methane production from highly concentrated organic wastewater (Hulshoff Pol et al., 1998). It is a robust system in which the produced methane gas provides the mixing of the reactor liquor. However, in sulfate reducing reactors mixing depends solely on the upflow of the waste stream, since the gases produced during sulfate reduction stay mainly in solution (Bijmans, 2008). Lens et al. (2001) investigated the effect of the superficial liquid up-flow velocity on the acidifying and sulfate reducing capacity of thermophilic $\left(55^{\circ} \mathrm{C}\right.$; $\left.\mathrm{pH} 6.0\right)$ granular sludge bed reactors treating partly acidified wastewater. Synthetic wastewater containing starch, sucrose, lactate, propionate and acetate and a low sulfate concentration $\left(\mathrm{COD} / \mathrm{SO}_{4}{ }^{2-}\right.$ ) ratio of 10 was fed at an HRT of about $5 \mathrm{~h}$ and volumetric organic loading rates (OLR) ranging from 4.9 to $40.0 \mathrm{~g} \mathrm{CODL}^{-1} \mathrm{~d}^{-1}$. At the end of the experiment, the sulfate level of the influent was slightly increased to a $\mathrm{COD} / \mathrm{SO}_{4}{ }^{2-}$ ratio of 8 . When imposing an OLR of $40.0 \mathrm{~g} \mathrm{CODL}^{-1} \mathrm{~d}^{-1}$, the acidification efficiency dropped to $80 \%$ and the sulfate reduction efficiency decreased to $50 \%$ in the UASB reactor producing acetate and propionate. At the higher organic loading rates, propionate was converted to n-butyrate and $n$-valerate. The effluent sulphide concentration was always below $200 \mathrm{mgL}^{-1}$, of which about $90 \%$ was present as undissociated $\mathrm{H}_{2} \mathrm{~S}$ (under the given conditions of $\mathrm{pH}$ 5.8-6.1 and $\left.55^{\circ} \mathrm{C}\right)$.

\subsubsection{Packed bed reactors (PBR)}

In this reactor, a carrier material is used to obtain well settable biomass by biofilm formation on the carrier material in contrast to granulation in a UASB. The carrier material provides a large surface area for bio-film formation (Speece, 1983). The use of different packed-bed reactors with various combinations of carrier material, carbon source and bacterial group is reported in literature for treating sulfate rich wastewaters (Table 8). Brahmacharimayum and Ghosh (2014) operated a PBR packed with polyurethane foam particle as the packing 
material to study its feasibility on $\mathrm{SO}_{4}{ }^{2-}$ reduction under different feeding and operating conditions of HRT, $\mathrm{COD} / \mathrm{SO}_{4}{ }^{2-}$ ratio and $\mathrm{SO}_{4}{ }^{2-}$ concentration. Chen et al. (1994) used a packed-bed bioreactor using sea sand as carrier matrix to study the kinetics and stoichiometry of sulfide formation. Waybrant et al. (2002) investigated the effect of packing reactive mixtures which were basically waste products. Elliott et al. (1998) conducted experiments in a PBR to investigate the effect of $\mathrm{pH}$ on the anaerobic sulfate reduction. Chang et al. (2000) demonstrated that solid waste materials including oak chips, spent oak from shiitake mushroom farms (SOS), spent mushroom compost (SMC), sludge from a wastepaper recycling plant (SWP) and organic-rich soil (ORS) can be used as electron donors and immobilization matrices to treat ARD. Kolmert and Johnson (2001) investigated the tolerance of mixed SRB culture to acidic environment in an up-flow packed-bed bioreactor, using porous glass beads as a carrier matrix. The average volumetric reduction rates of $0.010-0.013 \mathrm{gL}^{-1} \mathrm{~d}^{-1}$ were achieved in bioreactors containing mixed culture of acidophilic and neutrophilic SRB with a feed pH of 4.0. Kolmert and Johnson (2001) reported that sulfate reduction occurred at a $\mathrm{pH}$ of 3.0 but with a lower rate. Jong and Parry (2003) used an up-flow packed-bed bioreactor with sand as carrier matrix for anaerobic reduction of sulfate with mixed culture of SRB. The highest volumetric reduction rate of $0.019 \mathrm{gL}^{-1} \mathrm{~h}^{-1}$ was observed at a volumetric loading rate of $0.155 \mathrm{gL}^{-1} \mathrm{~h}^{-1}$ at $25^{\circ} \mathrm{C}$. Foucher et al. (2001) successfully used $\mathrm{CO}_{2}$ and $\mathrm{H}_{2}$ as carbon and energy source to treat Chessy mine drainage in an upflow packed-bed bioreactor with a special packing to provide good mass transfer between hydrogen and liquid. Lin and Lee (2001) studied anaerobic sulfate reduction in a fixed bed bio-film column bioreactor with Plastic Ballast rings as the supporting media for bio-film formation.

Table 8. Performance of UASB, CSTR, MBR and PBR used for treating sulfate rich wastewater

\begin{tabular}{|c|c|c|c|c|c|c|}
\hline Bacterial group & Substrate & $\begin{array}{l}\text { Reactor } \\
\text { Type }\end{array}$ & $\begin{array}{c}\text { Temp. } \\
\left({ }^{\circ} \mathrm{C}\right)\end{array}$ & Feed pH & $\begin{array}{l}\text { Volumetric } \\
\text { reduction rate } \\
\left(\mathrm{gL}^{-1} \mathrm{~h}^{-1}\right)\end{array}$ & Reference \\
\hline Mixed SRB & acetate & CSTR & 35 & $8 \pm 0.2$ & 0.076 & Moosa et al. (2005) \\
\hline Mixed SRB & acetate & CSTR & 35 & $8 \pm 0.2$ & 0.184 & Moosa et al. (2002) \\
\hline Activated sludge & molasses & CSTR & 30 & $4.5-5.5$ & - & Ren et al. (1997) \\
\hline $\begin{array}{l}\text { Desulfobacter } \\
\text { halotolerans }\end{array}$ & acetate, ethanol & MBR & $33 \pm 1$ & $7.2 \pm 0.2$ & 0.276 & Vallero et al. (2005) \\
\hline $\begin{array}{c}\text { Sulfate reducing } \\
\text { bacteria }\end{array}$ & sucrose & MBR & 35 & $6-6.5$ & - & Mizuno et al. (1998) \\
\hline $\begin{array}{c}\text { Granular } \\
\text { methanogenic } \\
\text { sludge } \\
\end{array}$ & acetate & UASB & $32 \pm 1$ & 8.3 & 0.584 & Muthumbi et al. (2001) \\
\hline Mixed culture & methanol & UASB & 30 & & 0.016 & Weijima et al. (2003) \\
\hline Mixed sludge & $\begin{array}{c}\text { Starch, sucrose, } \\
\text { lactate, acetate, } \\
\text { propionate }\end{array}$ & UASB & 55 & 6 & - & Lens et al. (2001) \\
\hline Mixed SRB & Lactate & PBR & 25 & 4.5 & 0.019 & Jong and Parry (2003) \\
\hline $\begin{array}{c}\text { Anaerobic sludge } \\
\text { From anaerobic } \\
\text { digesters }\end{array}$ & Landfill leachate & PBR & 37 & 6.5 & 0.015 & Thabet et al. (2009) \\
\hline Mixed SRB & Lactate & PBR & 22 & 7 & 0.228 & Baskaran and Nemati (2006) \\
\hline Mixed SRB & $\begin{array}{c}\mathrm{H}_{2} \& \mathrm{CO}_{2}+\text { sodium } \\
\text { acetate }\end{array}$ & PBR & 25 & 2.55 & 0.20 & Foucher et al. (2001) \\
\hline Mixed SRB & Lactate & PBR & 30 & $7.4 \pm 0.2$ & 0.067 & $\begin{array}{l}\text { Brahmacharimayum and Ghosh } \\
\text { (2014) }\end{array}$ \\
\hline
\end{tabular}

\subsection{Bioreactors employed for microaerobic process}

The major problem associated with the anaerobic treatment of sulfate-rich wastewater is the production of sulfide. The sulfide so produced is an undesirable product as it is reported to severely impair methanogenesis (Khanal and Huang, 2003), emanates unpleasant odor, causes corrosion of materials, affects human health and lowers the quality of biogas especially when sulfide content of biogas is above $0.7 \%$ by volume (Reis et al., 1988). Sulfide is one of the most toxic pollutants having a characteristic "rotten eggs" odor perceptible in fresh air in a dilution of $0.002 \mathrm{mgL}^{-1}$ of air (Buisman et al., 1989). Different sulfide removal techniques exist (Burgess et al., 
2001), including chemical precipitation as well as gas scrubbing in combination with chemical or biological oxidation processes. The biological reduction process can be made more effective if the sulfide produced can be converted to some other harmless and useful product such as elemental sulfur. As an alternative, introduction of limited quantities of oxygen/air to anaerobic bioreactors can be considered.

Under oxygen-limiting conditions, sulfur is the major end product of the sulfide oxidation, whereas under fully oxygenated condition, sulfide will be completely oxidized to sulfate (Cirne et al., 2008). Elemental sulfur production is favorable because it is neither inhibitory nor highly soluble, forming a solid precipitate that may produce dense sludge which settles well. The Gibb's free energy
$\left(\Delta \mathrm{G}_{0}, \mathrm{kJmol}^{-1}\right)$ calculated for the reactions involved in sulfide oxidation (Table 9) suggests that the reactions are feasible.

As given in Table 9, by regulating the oxygen dosing, microaerobic environment can be created in anaerobic reactors where sulfides can be oxidized into elemental sulfur. In addition, such conditions are sufficient to maintain an appropriate reducing environment essential for microorganisms responsible for sulfate reduction. The hydrogen sulfide so formed is oxidized to various other products indicating an effective competition of sulfideoxidizing microorganisms with other microorganisms for the available oxygen.

Table 9. Gibbs free energy values for the reactions involved in sulfide oxidation

\begin{tabular}{|c|c|c|c|}
\hline \multirow{2}{*}{ Reaction } & $\Delta \mathrm{G}_{0}\left(\mathrm{kJmol}^{-1}\right)$ & $\Delta \mathrm{G}_{0}\left(\mathrm{kJmol}^{-1}\right)$ & $\Delta \mathrm{G}_{0}\left(\mathrm{kJmol}^{-1}\right)$ \\
\hline & $\mathrm{pH}=7.0$ & $\mathrm{pH}=7.8$ & $\mathrm{pH}=8.4$ \\
\hline $\mathrm{H}_{2} \mathrm{~S}+0.5 \mathrm{O}_{2} \rightarrow \mathrm{S}^{0}+\mathrm{H}_{2} \mathrm{O}$ & -203.8 & -203.8 & -203.8 \\
\hline $\mathrm{HS}^{-}+0.5 \mathrm{O}_{2} \rightarrow \mathrm{S}^{0}+\mathrm{OH}^{-}$ & -209.1 & -204.7 & -201.2 \\
\hline $\mathrm{S}^{2-}+0.5 \mathrm{O}_{2}+2 \mathrm{H}^{+} \rightarrow 2 \mathrm{~S}^{0}+\mathrm{H}_{2} \mathrm{O}$ & -237.1 & -227.6 & -220.8 \\
\hline $\mathrm{H}_{2} \mathrm{~S}+2 \mathrm{O}_{2} \rightarrow \mathrm{SO}_{4}^{2-}+2 \mathrm{H}^{+}$ & -791.2 & -800.0 & -807.2 \\
\hline $\mathrm{HS}^{-}+2 \mathrm{O}_{2} \rightarrow \mathrm{SO}_{4}^{2-}+\mathrm{H}^{+}$ & -796.7 & -801.2 & -804.6 \\
\hline $\mathrm{S}^{2-}+2 \mathrm{O}_{2} \rightarrow \mathrm{SO}_{4}^{2-}$ & -824.1 & -824.1 & -824.1 \\
\hline
\end{tabular}

$\Delta G_{0}$ ': Standard Gibb's free energy for the reaction at $p H=7 . \Delta G_{0}\left(\mathrm{kJmol}^{-1}\right)$ values for the individual compounds for calculation are referred from Lide (2004), Thauer et al. (1977), Stumm and Morgan (1996) and Rossini et al. (1952).

\subsubsection{Mode of micro-aerobic regulation}

Direct introduction of oxygen/air into 'anaerobic' bioreactor systems for sulfide removal has been investigated previously during treatment of sulfate-rich wastewaters. By regulating the oxygen dosing, microaerobic conditions can be maintained in anaerobic reactors to maintain an acceptable reducing environment for anaerobic microorganisms to degrade the organic matter (Khanal and Huang, 2003; Fox and Venkatasubbiah, 1996; Zitomer and Shrout, 2000). Biological hydrogen sulfide treatment processes is more favored nowadays compared to other traditional physicochemical processes as it is less expensive and requires less or no utilization of chemicals (Lens and Hulshoff Pol, 2000; Syed et al., 2006). Biogas containing hydrogen sulfide from anaerobic treatment of high sulfate wastewaters can be reduced effectively both in fed-batch reactors (van der Zee et al., 2007), and in continuous reactors (Fox and Venkatasubbiah, 1996; Zitomer and Shrout, 2000; Khanal and Huang, 2003) by providing limited oxygen supply. Microorganisms such as Thiomicrospira sp. and Thiobacillus sp. are capable of performing sulfide oxidation even in anaerobic conditions like those in the anaerobic sludge digester depending on the oxygen availability (Tang et al., 2009). Pure cultures acclimatized to hydrogen sulfide, oxygen and nutrients are utilized in bio- scrubbers (Janssen et al., 2001) and biotrickling filters (Goncalves and Govind, 2009; Ramirez et al., 2009) to remove hydrogen sulfide biologically. In order to make biological hydrogen oxidation more cost effective, microoxygenation of the digester can be done as an alternative as the sludge already contains some sulfide oxidizing bacteria (Abatzoglou and Boivin, 2009). By supplying air or pure oxygen under micro-aerobic conditions to the 
headspace (Diaz et al., 2011) removal of hydrogen sulfide in the biogas was achieved. Removal of only hydrogen sulphide from the biogas or the total dissolved sulphide was observed depending on the sludge or biogas recirculation and the oxygen supply point (headspace or liquid phase). Sludge recirculation resulted in the removal of hydrogen sulphide from the biogas while dissolved sulphide removal also occurred with bio-gas recirculation (Díaz et al., 2010). Micro-aerobic supply of oxygen or air is thus a very practical and feasible method for hydrogen sulfide removal from anaerobic digesters without causing much harm to the anaerobic digestion process (Diaz et al., 2011; Díaz et al., 2010). Oxygen or air was introduced either directly into the reactor (Zitomer and Shrout, 2000; van der Zee et al., 2007; Zhou et al., 2007) or into the combined flow of effluent and biogas, right before this mixture entered a reservoir acting as a gas/liquid separator (Khanal and Huang, 2003). The mode of oxygen dosing was done differently in each of the reactor studies. Khanal and Huang (2003) applied an ORP system to monitor the oxygen dosing taking into account that the ORP varies linearly with the logarithm of oxygen concentration, the intrusion of oxygen, even at a level well beyond the detection limit of commercially available oxygen probe $\left(0.1 \mathrm{mgL}^{-1}\right)$, can be easily sensed by the ORP measurement. Chuang et al. (2005) used DO and ORP sensors in a floated bed micro-aerobic reactor for a moderate degree of oxidation of hydrogen sulfide. van der Zee et al. (2007) introduced a low airflow of $0.7-0.9 \mathrm{~m}^{3} \mathrm{~m}^{-}$ ${ }^{3} \mathrm{~d}^{-1}$, corresponding to a super-stoichiometric ratio of 8-10 mol $\mathrm{O}_{2}$ per mols. Diaz et al. (2010) maintained microaerobic conditions using the regulated flow of pure oxygen with a Cole-Parmer EW-32660-26 mass flow controller from an oxygen cylinder; when air was employed as an oxygen source and was injected into the headspace. A flow rate of $1.8 \pm 0.1 \mathrm{NmLmin}^{-1}$ representing $\sim 0.25 \mathrm{NL}$ of oxygen per $\mathrm{L}$ of feed sludge was provided to the sludge digesters to provide micro-oxygenation (Diaz et al., 2011). A controlled and continuous air injection (0.19 $\mathrm{Lmin}^{-1}$ ) given at $40 \%$ volume of an up-flow hybrid sulphidogenic reactor affected sulfide oxidation inside the reactor and enhanced the sulfate reduction efficiency (Sabumon, 2008). Xu et al. (2012) achieved sulfate removal efficiency of $81.5 \%$ and $S^{0}$ recovery of $71.8 \%$ in an integrated sulfate reducing and sulfate oxidizing EGSB bioreactor under micro-aerobic conditions by providing Dissolved Oxygen dose of $0.10-0.12 \mathrm{mgL}^{-1}$ by adjusting aeration flow rate in a separate $5 \mathrm{~L}$ vessel used as the aeration unit. Chemostats with working volume of $4 \mathrm{~L}$ operated at $35 \pm 0.5^{\circ} \mathrm{C}$ and a HRT of 15 days was maintained in a complete mixing condition by biogas recirculation at a flow rate of 3-4 $\mathrm{Lmin}^{-1}$ through a cadet pump (Cole Palmer, Model 7530-65) (Khanal and Huang, 2003). Krishnakumar et al. (2005) used a novel aerobic bioreactor, the reverse fluidized loop reactor (RFLR) (US Pat. No. 6,544,421) with biofilm carrier particle for recovering sulfur from aqueous sulfide at an HRT around 90 minutes. The air supply into the reactor was regulated with an on-off controller to maintain the redox potential required levels. Chuang et al. (2005) operated a system composed of an upward- flow anaerobic sludge blanket (UASB) reactor and a floated bed micro-aerobic reactor packed with elastic porous carriers maintained at dissolved oxygen below $0.5 \mathrm{mgL}^{-1}$. An average of $70 \pm 6 \%$ of sulfate was transformed to hydrogen sulfide in UASB reactor followed by the oxidation of most of the sulfide to elemental sulfur and sulfate in micro-aerobic reactor. At a HRT of $2.8 \mathrm{~h}$, sulfide was almost completely removed in the microaerobic reactor. Diaz et al. (2010) studied the performance of oxygen, air and nitrate for microaerobic removal of hydrogen sulfide in biogas from sludge in a 200-L digester with HRT of $\sim 20$ days. Hydrogen sulfide content was reduced from $15,811 \mathrm{mgN}^{-1} \mathrm{~m}^{3}$ to less than $400 \mathrm{mgN}^{-}$ ${ }^{1} \mathrm{~m}^{3}$ when oxygen was supplied $\left(0.25 \mathrm{~N} \mathrm{~m}^{3} \mathrm{~m}^{-3}\right.$ feed $)$ while introduction of air $\left(1.27 \mathrm{~N} \mathrm{~m}^{3} \mathrm{~m}^{-3}\right.$ feed $)$ successfully removed more than $99 \%$ of the hydrogen sulfide content, with a final concentration of $\sim 55 \mathrm{mgN}^{-1} \mathrm{~m}^{3}$. Two pilot-plant digesters with an HRT of $\sim 20 \mathrm{~d}$ were micro-oxygenated at a rate of $0.25 \mathrm{NL}$ per $\mathrm{L}$ of feed sludge with a removal efficiency higher than $98 \%$ (Diaz et al., 2011). Sulfide oxidation occurred in the headspace were different sulfide-oxidizing bacteria developed then, The supply of oxygen to the headspace was found to be the optimal dosing point resulting in elemental sulfur formation due to different sulfideoxidizing bacteria found present. Xu et al. (2012) reported the successful operation of an integrated SRB + SOB expanded granular sludge bed (EGSB) reactor under microaerobic condition. At DO $=0.10-0.12 \mathrm{mgL}^{-1}$, the sulfate removal efficiency reached $81.5 \%$ and the recovery of $S^{0}$ peaked at $71.8 \%$, higher which is the highest reported so far. At DO $>0.30 \mathrm{mgL}^{-1}$ activities of SRB were inhibited, leading to failure of the SRB + SOB reactor. Performance of microaerobic reactors used for treating sulfate rich wastewaters is given in Table 10. 
Table 10. Performance of microaerobic reactors used for treating sulfate rich wastewaters

\begin{tabular}{|c|c|c|c|c|c|c|c|c|c|c|c|c|c|}
\hline $\begin{array}{l}\text { Type of } \\
\text { reactor }\end{array}$ & $\begin{array}{c}\text { Reactor } \\
\text { volume } \\
\text { (Litre) }\end{array}$ & $\begin{array}{c}\text { Influent } \\
\text { Sulfate } \\
\left(\mathrm{g} \mathrm{L}^{-1}\right)\end{array}$ & $\begin{array}{c}\text { COD/Sulfate } \\
\text { ratio }\end{array}$ & $\begin{array}{c}\text { Sulfate } \\
\text { Removal } \\
\text { efficiency (\%) }\end{array}$ & $\begin{array}{c}S^{0} \\
\text { recovered }\end{array}$ & $\begin{array}{l}\text { Carbon } \\
\text { source }\end{array}$ & $\begin{array}{c}\text { Oxygen } \\
\text { introduction }\end{array}$ & $\mathrm{DO}\left(\mathrm{mgL}^{-1}\right)$ & $\begin{array}{l}\text { Aeration } \\
\text { level (L/d) }\end{array}$ & $\begin{array}{l}\text { Temp } \\
\left({ }^{\circ} \mathrm{C}\right)\end{array}$ & $\begin{array}{l}\text { Support } \\
\text { material }\end{array}$ & $\begin{array}{l}\text { HRT } \\
\text { (hrs) }\end{array}$ & Reference \\
\hline $\begin{array}{l}\text { Down-flow } \\
\text { fluidized bed } \\
\text { reactor }\end{array}$ & 2.3 & 3.9 & 0.66 & 75 & 52 & Lactate & $\begin{array}{l}\text { Filtered air at } \\
\text { bottom of } \\
\text { reactor }\end{array}$ & & 2.28 & 30 & Finely ground & 24 & $\begin{array}{l}\text { Celis-García et al. } \\
\text { (2008) }\end{array}$ \\
\hline \multirow[b]{2}{*}{ EGSB } & \multirow[b]{2}{*}{4} & \multirow[b]{2}{*}{$1 \pm 0.1$} & \multirow[b]{2}{*}{3} & 81.5 & 71.8 & \multirow[b]{2}{*}{ Lactate } & \multirow{2}{*}{$\begin{array}{c}\text { Separate vessel } \\
\text { for aeration to } \\
\text { maintain DO }\end{array}$} & $0.08-0.1$ & 14.4 & \multirow[b]{2}{*}{$30 \pm 1$} & \multirow[b]{2}{*}{-} & \multirow[b]{2}{*}{18} & \multirow[b]{2}{*}{ Xu et al. (2012) } \\
\hline & & & & 94.6 & 62.5 & & & $0.1-0.12$ & 28.8 & & & & \\
\hline \multirow{3}{*}{ Chemo-stat } & \multirow{3}{*}{4} & 1 & 10 & 43.4 & \multirow{3}{*}{$\begin{array}{l}\text { Dissolved } \\
\text { sulfides } \\
\text { UD }\end{array}$} & \multirow{3}{*}{ Glucose } & \multirow{3}{*}{$\begin{array}{l}\text { Recycled biogas } \\
\text { stream(pure } \mathrm{O}_{2} \text { ) }\end{array}$} & & \multirow{3}{*}{$\begin{array}{l}-230 \text { to } \\
-180 \text { ORP }\end{array}$} & \multirow{3}{*}{$35 \pm 0.5$} & \multirow{3}{*}{-} & \multirow{3}{*}{360} & \multirow{3}{*}{$\begin{array}{c}\text { Khanal and Huang } \\
\text { (2003) }\end{array}$} \\
\hline & & 3 & 3.33 & 22.4 & & & & & & & & & \\
\hline & & 5 & 2 & 59 & & & & & & & & & \\
\hline $\begin{array}{l}\text { Pilot plant } \\
\text { reactor }\end{array}$ & 250 & 2.2 & $42.7-21.8$ & - & - & Sludge & $\begin{array}{c}\text { Pure } \mathrm{O}_{2} \\
\text { Headspace }\end{array}$ & $\begin{array}{l}\sim 0.25 \mathrm{NL} \text { of } \\
\text { oxygen per } \mathrm{L} \\
\text { of feed } \\
\text { sludge }\end{array}$ & $\begin{array}{c}1.8 \pm 0.1 \\
\mathrm{NmLmin}\end{array}$ & $35 \pm 1$ & - & 480 & Diaz et al. (2011) \\
\hline
\end{tabular}




\subsubsection{Biokinetic coefficients}

The design of various waste water treatment processes based on hydraulic parameters are not sufficient considering the wide variation in the nature and composition of waste waters and various complex bio-chemical reactions taking place (Haydar and Aziz, 2009). It is because of this that estimation of bio-kinetic coefficients is required. The estimation of the coefficients assists in prediction of population dynamics, design and process performance of various bio-reactors used in sulfate reduction. Following this, biokinetic models have been employed by various studies to control and predict treatment plant operation performance, optimize the plant design and the results of scale-up pilot studies. Various Bio-kinetic models like Monod model, Contois
Model, Chen and Hashimoto model and Stover-Kicannon model, have been used to study the nature of sulfate reduction. Tables 11 and 12 respectively show the various Bio-kinetic models used and biokinetic coefficients obtained by different researchers. Along with these models various mathematical models which are modifications of the previously mentioned models that incorporate important factors such as $\mathrm{pH}$, temperature, type of reactor and inhibitory substances have been also used by researchers (Chou et al., 2008; Pallud and Cappellen, 2006; Bernardez et al., 2013; Dinkel et al., 2010; Somasundaram et al., 2009). All of these models used so far are growth models and are applicable up-to the growth phase of the bacterial growth curve.

Table 11. Various models used so far to determine bio-kinetic coefficients

\begin{tabular}{|c|c|c|c|c|c|}
\hline Model & Equation & Plot & Slope & Intercept & Reference \\
\hline Michalis-Menten & $\mathrm{v}=\frac{\mathrm{V}_{\mathrm{m}} \mathrm{C}_{\mathrm{s}}}{\mathrm{K}_{\mathrm{m}}+\mathrm{C}_{\mathrm{s}}}$ & $\frac{1}{v} \mathrm{vs} \frac{1}{C_{s}}$ & $\frac{K_{m}}{V_{m}}$ & $\frac{1}{V_{m}}$ & $\begin{array}{l}\text { Brandis-Heep } \\
\text { et al. (1983) }\end{array}$ \\
\hline Monod & $\mu=\frac{\mu_{\max } S}{K_{s}+S}$ & $\frac{1}{\mu}$ vs $\frac{1}{\mathrm{~S}}$ & $\frac{\mathrm{K}_{\mathrm{s}}}{\mu_{\max }}$ & $\frac{1}{\mu_{\max }}$ & $\begin{array}{l}\text { Monod } \\
(1949)\end{array}$ \\
\hline Contois & $\mu=\frac{\mu_{\max } S}{K_{s} X+S}$ & $\frac{1}{\mu} \mathrm{vs} \frac{\mathrm{S}_{0}}{\mathrm{~S}}$ & $\frac{\mathrm{K}_{\mathrm{s}}}{\mu_{\max }}$ & $\frac{1-K_{s}}{\mu_{\max }}$ & $\begin{array}{l}\text { Contois } \\
\text { (1959) }\end{array}$ \\
\hline $\begin{array}{l}\text { Chen and } \\
\text { Hashimoto }\end{array}$ & $\mu=\frac{\mu_{\max } \mathrm{S}}{\mathrm{K}_{\mathrm{s}} \mathrm{S}_{0}+\left(1-\mathrm{K}_{\mathrm{s}}\right) \mathrm{S}}$ & $\frac{1}{\mu}$ vs $\frac{X}{S}$ & $\frac{\mathrm{K}_{\mathrm{s}}}{\mu_{\max }}$ & $\frac{1}{\mu_{\max }}$ & $\begin{array}{l}\text { Chen and } \\
\text { Hashimoto } \\
(1980)\end{array}$ \\
\hline Kinetic model & $r_{s}=\left\{\frac{\mu_{\max } S}{K_{s}^{\prime} S_{0} X+S}-k_{d}\right\} \frac{X}{Y}$ & & & & $\begin{array}{l}\text { Moosa et al. } \\
\text { (2005) }\end{array}$ \\
\hline $\begin{array}{c}\text { Stover- } \\
\text { Kincannon model }\end{array}$ & $\frac{\mathrm{V}}{\mathrm{Q}\left(\mathrm{S}_{\mathrm{i}}-\mathrm{S}_{\mathrm{e}}\right)}=\frac{\mathrm{K}_{\mathrm{B}} \mathrm{S}_{\mathrm{i}}}{\mathrm{U}_{\max } \mathrm{VQ}}+\frac{1}{\mathrm{U}_{\max }}$ & $\frac{\mathrm{V}}{\mathrm{Q}\left(\mathrm{S}_{\mathrm{i}}-\mathrm{S}_{\mathrm{e}}\right)} \mathrm{vs} \frac{\mathrm{V}}{\mathrm{QS}_{\mathrm{i}}}$ & $\frac{\mathrm{K}_{\mathrm{B}}}{\mathrm{U}_{\max }}$ & $\frac{1}{U_{\max }}$ & $\begin{array}{l}\text { Kosińska and } \\
\text { Miśkiewicz } \\
\text { (2009) }\end{array}$ \\
\hline $\begin{array}{l}\text { First Order } \\
\text { Growth model }\end{array}$ & $\ln (X)=\mu t-B$ & $\ln x$ & $\mathrm{t}$ & $-B$ & $\begin{array}{l}\text { Silvia N. } \\
\text { Medircio } \\
(2006)\end{array}$ \\
\hline
\end{tabular}

Where $X$, bacterial population (concentration); $B$, constant; $\mu$ and $\mu_{\max }$ are specific growth rate and maximum specific growth rate $\left(\right.$ time $\left.^{-1}\right) ; S_{i}\left(\operatorname{or} S_{0}\right)$ and $S\left(\right.$ or $\left.S_{e}\right)$, threshold initial and effluent substrate (concentration); $K_{s}, K_{s}^{\prime \prime}, K_{B}$ are the Half velocity constant (concentration); $Y$, biomass yield (growth of bacterial mass in g/amount of substrate utilized in $g$ ); $k_{d}$, decay rate (time $\left.{ }^{-1}\right) ; U_{\text {max }}$ substrate utilization rate(concentration/time); $Q$, flow rate (volume/time); $r_{s}$, reaction rate (concentration/time); $t$, time 
Table 12. List of various bio-kinetic coefficients obtained for different SRB using bio-kinetic models

\begin{tabular}{|c|c|c|c|c|c|c|c|c|c|}
\hline \multirow[b]{2}{*}{ Reactor type } & \multirow[b]{2}{*}{$\begin{array}{l}\text { Carbon } \\
\text { source }\end{array}$} & \multirow[b]{2}{*}{ Major organisms } & \multirow[b]{2}{*}{ Model fit } & \multicolumn{5}{|c|}{ Bio-kinetic parameters } & \multirow[b]{2}{*}{ References } \\
\hline & & & & $\mu_{m}\left(h^{-1}\right)$ & $\begin{array}{l}\mathrm{Y}_{\text {COD }}\left(\mathrm{g} \text { biomass } \mathrm{g}^{-1}\right. \\
\text { COD utilized) }\end{array}$ & $\begin{array}{l}\mathrm{Y} \text { (g biomass } \\
\mathrm{g}^{-1} \text { sulfate } \\
\text { reduced) } \\
\end{array}$ & $K_{s}\left(g L^{-1}\right)$ & $\mathrm{V}_{\max }$ & \\
\hline Chemostat & Lactate & Mixed Culture & Contois & 0.2 & 0.08 & & 0.6 & & Oyekola et al. (2012) \\
\hline $\begin{array}{l}500 \mathrm{ml} \text { fermenter } \\
\text { flasks }\end{array}$ & $\begin{array}{c}\text { Acetate } \\
+\mathrm{CO}_{2}\end{array}$ & Desulfovibrio vulgaris & --- & 0.15 & '-- & 0.08 & --- & & $\begin{array}{c}\text { Badziong and Thauer } \\
\text { (1978) }\end{array}$ \\
\hline $115 \mathrm{ml}$ serum vials & Acetate & Desulfobacterpostgatei & --- & 0.03 & 0.07 & & & & \multirow{2}{*}{$\begin{array}{c}\text { Brandis-Heep et al. } \\
\text { (1983) }\end{array}$} \\
\hline Continuous chemostat & Acetate & Desulfobacterpostgatei & $\begin{array}{c}\text { MichaelisMenten } \\
\text { equation }\end{array}$ & --- & --- & --- & $77 \mu \mathrm{M}$ & $3.2 \mathrm{mmol} \mathrm{h}^{-1} \mathrm{~g}$ & \\
\hline Screw cap bottles & Acetate & Desulfobacter vibrioformis & ---- & --- & 4.6 & --- & --- & --- & Lien and Beeder (1997) \\
\hline $\begin{array}{c}50 \mathrm{ml} \text { screw cap } \\
\text { bottles }\end{array}$ & Acetate & Desulfobacter psychrotolerans & --- & --- & $0.07-0.075$ & --- & --- & --- & Tarpgaard et al. (2006) \\
\hline $\begin{array}{c}2 \text { L Continuous } \\
\text { mechanical stirred } \\
\text { reactor }\end{array}$ & Lactate & Desulfovibrio desulfuricans Essex 6 & --- & 0.054 & 0.04 & 0.07 & & & Cooney et al. (1996) \\
\hline $\begin{array}{l}\text { Batch culture, } 60 \mathrm{~mL} \\
\text { test tubes }\end{array}$ & Lactic acid & $\begin{array}{l}\text { Desulfovibrio desulfuricans, strain } \\
\text { NCIMB } 9467\end{array}$ & Monod & 0.04 & 0.01 & 2.09 & 1092 & --- & Herrera et al. (1991) \\
\hline $3 \mathrm{~L}$ glass reactor & Ethanol & Mixed culture & Monod & $\begin{array}{l}0.012- \\
0.013\end{array}$ & --- & --- & 0.2 & --- & Nagpal et al. (2000) \\
\hline $\begin{array}{l}300 \& 1000 \mathrm{~mL} \\
\text { Fermentation units }\end{array}$ & Glycerol & $\begin{array}{l}\text { Desulfovibrio baarsii, } \\
\text { Desulfomicrobium sp., and } \\
\text { Desufatomaculum sp. }\end{array}$ & $\begin{array}{l}\text { Mathematical model } \\
\text { using Monod equation }\end{array}$ & 0.02 & 0.28 & 0.23 & $2 \mathrm{ml} / \mathrm{L}$ & --- & Dinkel et al. (2010) \\
\hline
\end{tabular}




\section{Conclusion}

The environmental and industrial impacts caused due to sulfate makes it imperative to search for various treatment methods wherein biological sulfate reduction stands as an efficient process. The sulfate reducing bacteria involved in the processes are ubiquitous in anoxic and anaerobic environments, not only remain versatile in their metabolism, but are also able to thrive even in harsh climate and $\mathrm{pH}$ conditions. They can also utilize a wide range of of natural and synthetic carbon sources which defines their variability in terms of existence and functioning. Lower sludge production along with the generation of bio-film in attached growth processes like PBR, and membrane bio reactors makes it a more appropriate method to isolate the involved microorganisms from toxic environments. The choice of a suitable electron donor and process performance of a reactor for sulfate treatment depends upon the availability and effectiveness as well as operational costs involved. The recovery of sulfide to elemental sulfur is a great trend which makes it as one of the emerging technologies for sulfate removal.

However, very few studies have been carried out on the effects of air flow rates on the sizes and settling behavior of the elemental sulfur particles under microaerobic conditions. Optimization studies would result in maximum sulfate removal along with maximum elemental sulfur generation. Biological sulfate reduction would become a cost effective option to treat the industrial sulfate rich wastewaters if the sulfur recovery from the simultaneous sulfate reduction and sulfide oxidation is improved.

\section{Acknowledgements}

This research was supported by Council of Scientific and Industrial Research (CSIR), India [Project No. 22(0609)/12/EMRII].

\section{References}

Abatzoglou N. and Boivin S. (2009), A review of biogas purification processes. Biofuels, Bioproducts and Biorefining. 3(1), 42-71.

Alazard D. et al. (2010), Desulfosporosinus acidiphilus sp. nov.: a moderately acidophilic sulfate-reducing bacterium isolated from acid mining drainage sediments. Extremophiles, 14(3), 305-312.

Al-Zuhair S., El-Naas M.H. and Al-Hassani H. (2008), Sulfate inhibition effect on sulfate reducing bacteria.

Archilha N.C. et al. (2010), Effect of feeding strategy and COD/sulfate ratio on the removal of sulfate in an AnSBBR with recirculation of the liquid phase. Journal of Environmental Management, 91(8), 1756-1765.

Azabou S. et al. (2007), Isolation and characterization of a mesophilic heavy-metals-tolerant sulfate-reducing bacterium Desulfomicrobium sp. from an enrichment culture using phosphogypsum as a sulfate source. Journal of Hazardous Materials, 140(1-2), 264-270.

Backer L.C. (2000), Assessing the acute gastrointestinal effects of ingesting naturally occurring, high levels of sulfate in drinking water. Critical Reviews in Clinical Laboratory Sciences, 37(4), 389-400.

Badziong W. and Thauer R. (1978), Growth yields and growth rates of Desulfovibrio vulgaris (Marburg) growing on hydrogen plus sulfate and hydrogen plus thiosulfate as the sole energy sources. Archives of Microbiology, 117(2), 209214.

Baena S. et al. (1998), Desulfovibrio aminophilus sp. nov., a Novel Amino Acid Degrading and Sulfate Reducing Bacterium from an Anaerobic Dairy Wastewater Lagoon. Systematic and Applied Microbiology, 21(4), 498-504.

Bai H. et al. (2013), Treatment of acid mine drainage by sulfate reducing bacteria with iron in bench scale runs. Bioresource Technology, 128, 818-822.

Banks D. et al. (1997), Mine-water chemistry: the good, the bad and the ugly. Environmental Geology, 32(3), 157-174.

Baskaran V. and Nemati M. (2006), Anaerobic reduction of sulfate in immobilized cell bioreactors, using a microbial culture originated from an oil reservoir. Biochemical Engineering Journal, 31(2), 148-159.

Bernardez L.A. et al. (2013), A kinetic study on bacterial sulfate reduction. Bioprocess and Biosystems Engineering, 36(12), 1861-1869.

Bharathi L., Sathe V. and Chandramohan D. (1990), Effect of lead, mercury and cadmium on a sulphate-reducing bacterium. Environmental Pollution. 67(4), 361-374.

Bijmans M.F.M. (2008), Sulfate reduction under acidic conditions for selective metal recovery. Wageningen University, Wageningen, The Netherlands.

BIS (2012), Indian Standard Drinking Water-Specification Second Revision (IS 10500). Bureau of Indian Standards, New Delhi.

Boshoff G., Duncan J. and Rose P.D. (2004), Tannery effluent as a carbon source for biological sulphate reduction. Water Research, 38(11), 2651-2658.

Bowell R.J. (2000), Sulphate and salt minerals: the problem of treating mine waste. Mining Environmental Management, 8, 11-13.

Brahmacharimayum B. and Ghosh P.K. (2014), Sulfate bioreduction and elemental sulfur formation in a packed bed reactor. Journal of Environmental Chemical Engineering.

Brandis-Heep A. et al. (1983), Anaerobic acetate oxidation to $\mathrm{CO} 2$ by Desulfobacter postgatei. Archives of Microbiology, 136(3), 222-229.

Brunner B. and Bernasconi S.M. (2005), A revised isotope fractionation model for dissimilatory sulfate reduction in sulfate reducing bacteria. Geochimica et Cosmochimica Acta, 69(20), 4759-4771.

Buisman C.J.N. et al. (1989), Biotechnological process for sulphide removal with sulphur reclamation. Acta Biotechnologica, 9, 255-267.

Burgess J.E., Parsons S.A. and Stuetz R.M. (2001), Developments in odour control and waste gas treatment biotechnology: a review. Biotechnology Advances, 19(1), 35-63.

Cabrera G. et al. (2006), Toxic effects of dissolved heavy metals on Desulfovibrio vulgaris and Desulfovibrio sp. strains. Journal of Hazardous Materials, 135(1), 40-46.

Cao H.-h. et al. (2011), Effect of COD/Sulfate Ratios on Batch Anaerobic Digestion Using Sulfate-Reduction Bacteria. in Bioinformatics and Biomedical Engineering, (iCBBE) 2011 5th International Conference on.

Carrondo M.J.T., Silva J.M.C., Figueira M.I.I., Ganho R.M.B. and Oliveira J.F.S. (1983), Anaerobic filter treatment of molasses fermentation wastewater. Water Science Technology, 15, 117-128.

Celis-García L.B., González-Blanco G. and Meraz M. (2008), Removal of sulfur inorganic compounds by a biofilm of 
sulfate reducing and sulfide oxidizing bacteria in a down-flow fluidized bed reactor. Journal of Chemical Technology \& Biotechnology, 83(3), 260-268.

Cervantes F.J., Pavlostathis S.G., and van Haandel A.C. (2006), Advanced Biological Treatment Processes for Industrial Wastewaters: Principles and Applications. IWA Publishing: 12 Caxton street, London SW1H 0QS, UK, p. 345.

Chang I.S., Shin P.K., and Kim B.H. (2000), Biological treatment of acid mine drainage under sulphate-reducing conditions with solid waste materials as substrate. Water Research, 34(4), 1269-1277.

Chen C.-I., Mueller R.F. and Griebe T. (1994), Kinetic analysis of microbial sulfate reduction by desulfovibrio desulfuricans in an anaerobic upflow porous media biofilm reactor. Biotechnology and Bioengineering, 43(4), 267-274.

Chen Y.R. and Hashimoto A.G. (1980), Substrate utilization kinetic model for biological treatment process. Biotechnology and Bioengineering, 22(10), 2081-2095.

Choi E. and Rim J.M. (1991), Competition and inhibition of sulfate reducers and methane producers in anaerobic treatment. Water Science \& Technology, 23(7-9), 1259-1264.

Chou H.-H. et al. (2008), Competitive reaction kinetics of sulfatereducing bacteria and methanogenic bacteria in anaerobic filters. Bioresource Technology, 99(17), 8061-8067.

Chuang S.H., Pai T.Y. and Horng R.Y. (2005), Biotreatment of Sulfate-Rich Wastewater in an Anaerobic/Micro-Aerobic Bioreactor System. Environmental Technology, 26(9), 9931002.

Chuichulcherm S. et al. (2001), Treatment of metal-containing wastewaters with a novel extractive membrane reactor using sulfate-reducing bacteria. Journal of Chemical Technology \& Biotechnology, 76(1), 61-68.

Cirne D. et al. (2008), Control of sulphide during anaerobic treatment of S-containing wastewaters by adding limited amounts of oxygen or nitrate. Reviews in Environmental Science and Biotechnology, 7(2), 93-105.

Colleran E., Finnegan S. and Lens P. (1995), Anaerobic treatment of sulphate-containing waste streams. Antonie Van Leeuwenhoek, 67(1), 29-46.

Colleran E., Finnegan S. and O'Kefee R.B. (1994), Anaerobic digestion of high sulphate containing waste water from the industrial production of citric acid. Water Science \& Technology, 30, 263-273.

Contois D.E. (1959), Kinetics of Bacterial Growth: Relationship between Population Density and Specific Growth Rate of Continuous Cultures, Microbiology, 21, 40-50.

Cooney M.J. et al. (1996), Physiologic studies with the sulfatereducing bacterium Desulfovibrio desulfuricans: Evaluation for use in a biofuel cell. Enzyme and Microbial Technology, 18(5), 358-365.

Costabile A.L.O. et al. (2011), Temperature and feed strategy effects on sulfate and organic matter removal in an AnSBB. Journal of Environmental Management, 92(7), 1714-1723.

Crine M. et al. (1999), Sulphate reduction optimization in the presence of Desulfotomaculum acetoxidans and Desulfobacter postgatei species. Application of factorial design and factorial correspondance analysis methods, in Process Metallurgy, Elsevier, pp. 759-768.

Dague R.R. (1993), Anaerobic sequencing batch reactor. Google Patents.

de Smul A., Goethals L. and Verstraete W. (1999), Effect of COD to sulphate ratio and temperature in expanded-granularsludge-blanket reactors for sulphate reduction. Process Biochemistry, 34(4), 407-416.
Díaz I. et al. (2010), Performance evaluation of oxygen, air and nitrate for the microaerobic removal of hydrogen sulphide in biogas from sludge digestion. Bioresource Technology, 101(20), 7724-7730.

Diaz I. et al. (2011), Effect of oxygen dosing point and mixing on the microaerobic removal of hydrogen sulphide in sludge digesters. Bioresource technology, 102(4), 3768-3775.

Dijkman H. (1995), Biological gas desulfurization, Med Fac Lanbouw, University Ghent 60/4b, pp. 2677-2684.

Dinkel V.G. et al. (2010), Kinetics of anaerobic biodegradation of glycerol by sulfate-reducing bacteria. Applied Biochemistry and Microbiology, 46(7), 712-718.

Dries J. et al. (1998), High rate biological treatment of sulfaterich wastewater in an acetate-fed EGSB reactor. Biodegradation, 9(2), 103-111.

Dvorak D.H. et al. (1992), Treatment of metal-contaminated water using bacterial sulfate reduction: Results from pilotscale reactors. Biotechnology and Bioengineering, 40(5), 609616.

Elliott P., Ragusa S. and Catcheside D. (1998), Growth of sulfatereducing bacteria under acidic conditions in an upflow anaerobic bioreactor as a treatment system for acid mine drainage. Water Research, 32(12), 3724-3730.

Fang H. (1997), Effect of Sulfate on Anaerobic Degradation of Benzoate in UASB Reactors. Journal of Environmental Engineering, 123(4), 320.

Findley J.E. and Akagi J.M. (1970), Role of thiosulfate in bisulfite reduction as catalyzed by Desulfovibrio vulgaris. Journal of Bacteriology, 103(3), 741-744.

Fitz R.M. and Cypionka H. (1990), Formation of thiosulfate and trithionate during sulfite reduction by washed cells of Desulfovibrio desulfuricans. Archives of Microbiology, 154(4), 400-406.

Foucher S. et al. (2001), Treatment by sulfate-reducing bacteria of Chessy acid-mine drainage and metals recovery. Chemical Engineering Science, 56(4), 1639-1645.

Fox P. and Venkatasubbiah V. (1996), Coupled anaerobic/aerobic treatment of high-sulfate wastewater with sulfate reduction and biological sulfide oxidation. Water Science and Technology, 34(5-6), 359-366.

Fukui M. and Takii S. (1994), Kinetics of sulfate respiration by free-living and particle-associated sulfate-reducing bacteria. FEMS Microbiology Ecology, 13(4), 241-247.

Galiana-Aleixandre M.-V., Mendoza-Roca J.-A. and Bes-Pia A. (2011), Reducing sulfates concentration in the tannery effluent by applying pollution prevention techniques and nanofiltration. Journal of Cleaner Production, 19(1), 91-98.

Goncalves J.J. and Govind R. (2009), Enhanced biofiltration using cell attachment promotors. Environmental Science \& Technology, 43(4), 1049-1054.

Gordon A.R. and Robinson J.D.F. (1995), Acid Drainage from Mines, The Geographical Journal, 161(1), 47-54.

Habets L.H.A. and de Vegt A.L. (1991), Anaerobic treatment of bleached TMP and CTMP effluent in the biopaq UASB system. Water Science \& Technology, 24(3-4), 331-345.

Hansen T.A. (1994), Metabolism of sulfate-reducing prokaryotes. Antonie Van Leeuwenhoek, 66(1-3), 165-185.

Hao O.J. et al. (1994), Effects of metal additions on sulfate reduction activity in wastewaters. Toxicological \& Environmental Chemistry, 46(4), 197-212. 
Haydar S. and Aziz J.A. (2009), Kinetic Coefficients for the Biological Treatment of Tannery Wastewater Using Activated Sludge Process. Engineering Science and Applied Science, 5, 39-43.

Herrera L. et al. (1991), Desulfovibrio desulfuricans growth kinetics. Environmental Toxicology and Water Quality, 6(2), 225-237.

Herrera L. et al. (1997), Biological process for sulfate and metals abatement from mine effluents. Environmental Toxicology and Water Quality, 12(2), 101-107.

Hulshoff Pol L.W.et al. (1998), Anaerobic treatment of sulphaterich wastewaters. Biodegradation, 9(3), 213-224.

Icgen B. and Harrison S. (2006), Exposure to sulfide causes populations shifts in sulfate-reducing consortia. Research in Microbiology, 157(8), 784-791.

Ingvorsen K., Yde Nielsen M. and Joulian C. (2003), Kinetics of bacterial sulfate reduction in an activated sludge plant. FEMS Microbiology Ecology, 46(2), 129-137.

Ishimoto M. and Yagi T. (1961), Biochemical Studies on SulfateReducing Bacteria: IX. Sulfite Reductase. Journal of Biochemistry, 49(2): 103-109.

Janssen A.J.H., Ruitenberg R. and Buisman C.J.N. (2001), Industrial applications of new sulfur biotechnology. Water Science \& Technology, 44, 85-90.

Jhung J.K. and Choi E. (1995), A comparative study of UASB and anaerobic fixed film reactors with development of sludge granulation. Water Research, 29(1), 271-277.

Jong T. and Parry D.L. (2003), Removal of sulfate and heavy metals by sulfate reducing bacteria in short-term bench scale upflow anaerobic packed bed reactor runs. Water Research, 37(14), 3379-3389.

Kabdasli I., Tünay O., and Orhon D. (1995), Sulfate removal from indigo dyeing textile wastewaters. Water Science and Technology. 32(12), 21-27.

Kaksonen A.H. (2004), The performance, kinetics and microbiology of sulfidogenic fluidized-bed reactors treating acidic metal and sulfate-containing wastewater. Tampere University of Technology.

Kaksonen A.H. and Puhakka J.A. (2007), Sulfate Reduction Based Bioprocesses for the Treatment of Acid Mine Drainage and the Recovery of Metals. Engineering in Life Sciences, 7(6), 541-564.

Khanal S. and Huang J. (2003), Anaerobic Treatment of High Sulfate Wastewater with Oxygenation to Control Sulfide Toxicity. Journal of Environmental Engineering, 129(12), 1104-1111.

Khanal S.K. and Huang J.-C. (2003), ORP-based oxygenation for sulfide control in anaerobic treatment of high-sulfate wastewater. Water Research, 37(9), 2053-2062.

Kimura S., Hallberg K.B. and Johnson D.B. (2006), Sulfidogenesis in low $\mathrm{pH}$ (3.8-4.2) media by a mixed population of acidophilic bacteria. Biodegradation, 17(2), 159-167.

Knoblauch C., Sahm K. and Jorgensen B.B. (1999), Psychrophilic sulfate-reducing bacteria isolated from permanently cold Arctic marine sediments: description of Desulfofrigus oceanense gen. nov., sp. nov., Desulfofrigus fragile sp. nov., Desulfofaba gelida gen. nov., sp. nov., Desulfotalea psychrophila gen. nov., sp. nov. and Desulfotalea arctica sp. nov. International Journal of Systematic and Evolutionary Microbiology, 49(4), 1631-1643.
Kobayashi K., Tachibana S. and Ishimoto M. (1969), Intermediary formation of trithionate in sulfite reduction by a sulfatereducing bacterium. Journal of Biochemistry, 65(1), 155-157.

Kolmert Å. and Johnson D.B. (2001), Remediation of acidic waste waters using immobilised, acidophilic sulfate-reducing bacteria. Journal of Chemical Technology \& Biotechnology, 76(8), 836-843.

Kosińska K. and Miśkiewicz T. (2009), Performance of an anaerobic bioreactor with biomass recycling, continuously removing $C O D$ and sulphate from industrial wastes. Bioresource Technology, 100(1), 86-90.

Krishnakumar B. et al. (2005), Treatment of sulphide containing wastewater with sulphur recovery in a novel reverse fluidized loop reactor (RFLR), Water Research, 39(4), 639647.

Krishnanand Y.M. and Parkin G.F. (1996), Kinetics of Growth, Substrate Utilization and Sulfide Toxicity for Propionate, Acetate, and Hydrogen Utilizers in Anaerobic Systems. Water Environment Research, 68(7), 1099-1106.

Kristensen E., et al. (2000), Sulfur cycling of intertidal Wadden Sea sediments (Konigshafen, Island of Sylt, Germany): sulfate reduction and sulfur gas emission. Journal of Sea Research, 43(2), 93-104.

Lens P. and Hulshoff Pol L.W. (2000), Environmental Technologies to Treat Sulfur Pollution: Principles and Engineering, IWA Publishing, London.

Lens P. et al. (2001), Effect of the liquid upflow velocity on thermophilic sulphate reduction in acidifying granular sludge reactors. Environmental Technology, 22(2), 183-193.

Lens P.N. et al. (1995), Sulfate reducing and methane producing bacteria in aerobic wastewater treatment systems. Water Research, 29(3), 871-880.

Lens P.N.L. et al. (1998), Biotechnological Treatment of SulfateRich Wastewaters. Critical Reviews in Environmental Science and Technology, 28(1), 41-88.

Liamleam W. and Annachhatre A.P. (2007), Electron donors for biological sulfate reduction. Biotechnology Advances, 25(5), 452-463.

Lide D.R. (2004), CRC handbook of chemistry and physics, CRC Press.

Lien T. and Beeder J. (1997), Desulfobacter vibrioformis sp. nov., a sulfate reducer from a water-oil separation system. International Journal of Systematic Bacteriology, 47(4), 11241128.

Lin Y.H. and Lee K.K. (2001), Verification of Anaerobic Biofilm Model for Phenol Degradation with Sulfate Reduction. Journal of Environmental Engineering, 127(2), 119-125.

Lo K.V., Chen A. and Liao P.H. (1990), Anaerobic treatment of baker's yeast wastewater: II. Sulfate removal. Biomass, 23(1), 25-37.

Lopes S.I. et al. (2007), Effect of $\mathrm{COD} / \mathrm{SO}(4)(2-)$ ratio and sulfide on thermophilic ( 55 degrees $\mathrm{C}$ ) sulfate reduction during the acidification of sucrose at $\mathrm{pH}$ 6., Water Research, 41(11), 2379-2392.

Lopes S.I.C. et al. (2007), Low pH (6, 5 and 4) sulfate reduction during the acidification of sucrose under thermophilic $\left(55^{\circ} \mathrm{C}\right)$ conditions. Process Biochemistry, 42(4), 580-591. 
Lopes S.I.C., Capela M.I. and Lens P.N.L. (2010), Sulfate reduction during the acidification of sucrose at $\mathrm{pH} 5$ under thermophilic $\left(55^{\circ} \mathrm{C}\right)$ conditions. II: Effect of sulfide and $\mathrm{COD} / \mathrm{SO}_{4}{ }^{2-}$ ratio. Bioresource Technology, 101(12), 42784284.

Madigan M.T. et al. (2009), Brock Biology of Microorganisms. 12th ed, Prentice Hall, Upper Saddle River, NJ.

Martins M. et al. (2009), Characterization and activity studies of highly heavy metal resistant sulphate-reducing bacteria to be used in acid mine drainage decontamination. Journal of Hazardous Materials, 166(2), 706-713.

Masigol M.A., Moheb A. and Mehrabani-Zeinabad A. (2012), An experimental investigation into batch electrodialysis process for removal of sodium sulfate from magnesium stearate aqueous slurry. Desalination, 300, 12-18.

Mendez R., Lema J.M. and Soto M. (1995), Treatment of seafood-processing wastewater in mesophilic and thermophilic anaerobic filters. Water Environment Research, 67(1), 33-45.

Mizuno O., Takagi H. and Noike T. (1998), Biological sulfate removal in an acidogenic bioreactor with an ultrafiltration membrane system. Water Science and Technology, 38(4-5), 513-520.

Mizuno O., Li Y.Y. and Noike T. (1998), The behavior of sulfatereducing bacteria in acidogenic phase of anaerobic digestion. Water Research, 32(5), 1626-1634.

MoEF (1986), Gazette of India in Environment (Protection) Rules, New Delhi.

Mogensen G.L., Kjeldsen K.U. and Ingvorsen K. (2005), Desulfovibrio aerotolerans sp. nov., an oxygen tolerant sulphate-reducing bacterium isolated from activated sludge. Anaerobe 11(6), 339-349.

Mohan S.V. et al. (2005), Bioaugmentation of an anaerobic sequencing batch biofilm reactor (AnSBBR) with immobilized sulphate reducing bacteria (SRB) for the treatment of sulphate bearing chemical wastewater. Process Biochemistry, 40(8), 2849-2857.

Monod J. (1949), The growth of bacterial cultures. Annual Reviews in Microbiology, 3(1), 371-394.

Moon C. et al. (2013), Modeling sulfate removal by inhibited mesophilic mixed anaerobic communities using a statistical approach. Water Research, 47(7), 2341-2351.

Moosa S. and Harrison S.T.L. (2006), Product inhibition by sulphide species on biological sulphate reduction for the treatment of acid mine drainage. Hydrometallurgy, 83(1-4), 214-222.

Moosa S., Nemati M. and Harrison S.T.L. (2002), A kinetic study on anaerobic reduction of sulphate, Part I: Effect of sulphate concentration. Chemical Engineering Science, 57(14), 27732780.

Moosa S., Nemati M. and Harrison S.T.L. (2005), A kinetic study on anaerobic reduction of sulphate, part II: incorporation of temperature effects in the kinetic model. Chemical Engineering Science, 60(13), 3517-3524.

Muthumbi W. et al. (2001), Microbial sulfate reduction with acetate: process performance and composition of the bacterial communities in the reactor at different salinity levels. Applied Microbiology and Biotechnology, 55(6), 787793.
Muyzer G. and Stams A.J.M. (2008), The ecology and biotechnology of sulphate-reducing bacteria. Nature Reviews Microbiology, 6(6), 441-454.

Nagpal S. et al. (2000), Ethanol utilization by sulfate-reducing bacteria: An experimental and modeling study. Biotechnology and Bioengineering, 70(5), 533-543.

Name T. and Sheridan C. (2014), Remediation of acid mine drainage using metallurgical slags. Minerals Engineering, 64, 15-22.

Neculita C.M. and Zagury G.J. (2008), Biological treatment of highly contaminated acid mine drainage in batch reactors: Long-term treatment and reactive mixture characterization. Journal of Hazardous Materials, 157(2-3), 358-366.

Neculita C.-M., Zagury G.J. and Bussière B. (2007), Passive Treatment of Acid Mine Drainage in Bioreactors using Sulfate-Reducing Bacteria. Journal of Environmental Quality, 36(1), 1-16.

Nevatalo L.M. et al. (2010), Biological hydrogen sulfide production in an ethanol-lactate fed fluidized-bed bioreactor. Bioresource Technology, 101(1), 276-284.

Obuekwe C.O. et al. (1981), Corrosion of Mild Steel in Cultures of Ferric Iron Reducing Bacterium Isolated from Crude Oil I. Polarization Characteristics. Corrosion, 37(8), 461-467.

O'Flaherty V. and Colleran E. (1999), Effect of sulphate addition on volatile fatty acid and ethanol degradation in an anaerobic hybrid reactor. I: process disturbance and remediation. Bioresource Technology, 68(2), 101-107.

O'Flaherty V. et al. (1998), Effect of pH on growth kinetics and sulphide toxicity thresholds of a range of methanogenic, syntrophic and sulphate-reducing bacteria. Process Biochemistry, 33(5), 555-569.

Okabe S. et al. (1995), Sulfide product inhibition of Desulfovibrio desulfuricans in batch and continuous cultures. Water Research, 29(2), 571-578.

Okabe S., Nielsen P.H. and Charcklis W.G. (1992), Factors affecting microbial sulfate reduction by Desulfovibrio desulfuricans in continuous culture: limiting nutrients and sulfide concentration. Biotechnology and Bioengineering, 40(6), 725-734.

Omil F. et al. (1998), Long-term competition between sulfate reducing and methanogenic bacteria in UASB reactors treating volatile fatty acids. Biotechnology and Bioengineering, 57(6), 676-685.

Oyekola O.O. van Hille R.P. and Harrison S.T.L. (2010), Kinetic analysis of biological sulphate reduction using lactate as carbon source and electron donor: Effect of sulphate concentration. Chemical Engineering Science, 65(16), 47714781.

Oyekola O.O., Harrison S.T.L. and van Hille R.P. (2012),. Effect of culture conditions on the competitive interaction between lactate oxidizers and fermenters in a biological sulfate reduction system. Bioresource Technology, 104, 616-621.

Pallud C.I. and Cappellen V.P. (2006), Kinetics of microbial sulfate reduction in estuarine sediments. Geochimica et Cosmochimica Acta, 70, 1148-1162.

Parkin G. and Owen W. (1986), Fundamentals of Anaerobic Digestion of Wastewater Sludges. Journal of Environmental Engineering, 112(5), 867-920.

Percheron G., Bernet N. and Moletta R. (1997), Start-up of anaerobic digestion of sulfate wastewater. Bioresource Technology, 61(1), 21-27. 
Perry R.H., Green D.W. and Maloney J.O. (1984), Perry's chemical engineer's handbook, in Perry's chemical engineer's handbook, McGraw-Hill Book.

Pikuta E.V. et al. (2003), Desulfonatronum thiodismutans sp. nov., a novel alkaliphilic, sulfate-reducing bacterium capable of lithoautotrophic growth. International Journal of Systematic and Evolutionary Microbiology, 53(5), 1327-1332.

Pineau S. et al.(2008), Formation of the Fe(II-III) hydroxysulphate green rust during marine corrosion of steel associated to molecular detection of dissimilatory sulphitereductase. Corrosion Science, 50(4), 1099-1111.

Postgate J.R. (1984), The Sulfate Reducing Bacteria, 2nd ed, Cambridge University Press, UK.

Ramirez M. et al. (2009), Removal of hydrogen sulfide by immobilized Thiobacillus thioparus in a biotrickling filter packed with polyurethane foam. Bioresource Technology, 100(21), 4989-4995.

Rao A.G. et al. (2007), Microbial conversion of sulfur dioxide in flue gas to sulfide using bulk drug industry wastewater as an organic source by mixed cultures of sulfate reducing bacteria. Journal of Hazardous Materials, 147(3), 718-725.

Reis M.A. et al. (1992), Effect of hydrogen sulfide on growth of sulfate reducing bacteria, Biotechnology and Bioengineering, 40(5), 593-600.

Reis M.A.M., Goncalves L.M.D. and Carrondo M.J.T. (1988), Sulphate removal in acidogenic phase anaerobic digestion. Environmental Technology Letters, 9(8), 775-784.

Ren N., Wang B. and Huang J.-C. (1997), Ethanol-type fermentation from carbohydrate in high rate acidogenic reactor. Biotechnology and Bioengineering, 54(5), 428-433.

Rodriguez R.P. et al. (2012), Assessment of a UASB reactor for the removal of sulfate from acid mine water. International Biodeterioration \& Biodegradation, 74, 48-53.

Rosnes J.T., Torsvik T. and Lien T. (1991), Spore-Forming Thermophilic Sulfate-Reducing Bacteria Isolated from North Sea Oil Field Waters. Applied and Environmental Microbiology, 57(8), 2302-2307.

Rossini F.D., Wagman D.D. and Evans W.H. (1952), Selected values of chemical thermodynamic properties, US Government Printing Office Washington, DC.

Sabumon P.C. (2008), Development of enhanced sulphidogenesis process for the treatment of wastewater having low $\mathrm{COD} / \mathrm{SO}_{2}$ ratio. Journal of Hazardous Materials, 159(2-3), 616-625.

Sahinkaya E. (2009), Microbial sulfate reduction at low $\left(8^{\circ} \mathrm{C}\right)$ temperature using waste sludge as a carbon and seed source. International Biodeterioration \& Biodegradation, 63(3), 245-251.

Sanchez R.F., Cordoba P. and Sineriz F. (1997), Use of the USAB for the anaerobic treatment of stillage from sugar-cane molasses. Biotechnology and Bioengineering, 27(12), 17101716.

Sani R.K., Peyton B.M. and Brown L.T. (2001), Copper-induced inhibition of growth of Desulfovibrio desulfuricans G20: assessment of its toxicity and correlation with those of zinc and lead. Applied and Environmental Microbiology, 67(10), 4765-4772.

Sarti A. and Zaiat M. (2011), Anaerobic treatment of sulfate-rich wastewater in an anaerobic sequential batch reactor (AnSBR) using butanol as the carbon source. Journal of Environmental Management, 92(6), 1537-1541.
Sarti A. et al. (2009), The treatment of sulfate-rich wastewater using an anaerobic sequencing batch biofilm pilot-scale reactor. Desalination, 249(1), 241-246.

Sarti A. et al. (2010), Microbial processes and bacterial populations associated to anaerobic treatment of sulfaterich wastewater. Process Biochemistry, 45(2), 164-170.

Sawicka J.E., Jorgensen B.B. and Bruchert V. (2012), Temperature characteristics of bacterial sulfate reduction in continental shelf and slope sediments. Biogeosciences Discussions, 9(1), 673-700.

Shen Y. and Buick R. (2004), The antiquity of microbial sulfate reduction. Earth-Science Reviews, 64(3), 243-272.

Sheoran A.S., Sheoran V. and Choudhary R.P. (2010), Bioremediation of acid-rock drainage by sulphate-reducing prokaryotes: A review. Minerals Engineering, 23(14), 10731100.

Silva A.J. et al. (2002), Sulphate removal from industrial wastewater using a packed-bed anaerobic reactor. Process Biochemistry, 37(9), 927-935.

Silva A.M., Lima R.M.F. and Leao V.A. (2012), Mine water treatment with limestone for sulfate removal. Journal of Hazardous Materials, 221-222, 45-55.

Silva R., Cadorin L. and Rubio J. (2010), Sulphate ions removal from an aqueous solution: I. Co-precipitation with hydrolysed aluminum-bearing salts. Minerals Engineering, 23(15), 1220-1226.

Medircio S.N., Leão V.A. and Teixeira M.C. (2006), Specific growth rate of sulfate reducing bacteria in the presence of manganese and cadmium. Journal of Hazardous Materials, 143, 593-596.

Sipma J. et al. (1999), Thermophilic sulphate reduction in upflow anaerobic sludge bed reactors under acidifying conditions. Process Biochemistry, 35(5), 509-522.

Somasundaram V., Philip L. and Bhallamudi S.M. (2009), Experimental and mathematical modeling studies on $\mathrm{Cr}(\mathrm{VI})$ reduction by $C R B, S R B$ and IRB, individually and in combination. Journal of Hazardous Materials, 172(2-3), 606617.

Song Y.-C. et al. (1998), Influence of electron donor and toxic materials on the activity of sulfate reducing bacteria for the treatment of electroplating wastewater. Water Science and Technology, 38(4-5), 187-194.

Sonne-Hansen J. and Ahring B.K. (1999), Thermodesulfobacterium hveragerdense sp.nov., and Thermodesulfovibrio islandicus sp.nov., Two Thermophilic Sulfate Reducing Bacteria Isolated from a Icelandic Hot Spring. Systematic and Applied Microbiology, 22(4), 559-564.

Speece R.E. (1983), Anaerobic biotechnology for industrial wastewater treatment. Environmental Science \& Technology, 17(9), 416A-427A.

Stumm W. and Morgan J.J. (1996), Aquatic chemistry: Chemical equilibria and rates in natural waters, John Wiley \& Sons. Inc., New York, p. 1022.

Sun C. et al. (2010), Effects of SRB on cathodic protection of Q235 steel in soils. Materials and Corrosion, 61(9), 762-767.

Syed M. et al. (2006), Removal of hydrogen sulfide from gas streams using biological processes - A review. Canadian Biosystems Engineering, 48, 2. 
Tang K., Baskaran V. and Nemati M. (2009), Bacteria of the sulphur cycle: An overview of microbiology, biokinetics and their role in petroleum and mining industries. Biochemical Engineering Journal, 44(1), 73-94.

Tarpgaard I., Boetius A. and Finster K. (2006), Desulfobacter psychrotolerans sp. nov., a new psychrotolerant sulfatereducing bacterium and descriptions of its physiological response to temperature changes. Antonie Van Leeuwenhoek, 89(1), 109-124.

Thabet O.B.D. et al. (2009), Anaerobic degradation of landfill leachate using an upflow anaerobic fixed-bed reactor with microbial sulfate reduction. Journal of Hazardous Materials, 167(1-3), 1133-1140.

Thauer R.K., Jungermann K. and Decker K. (1977), Energy conservation in chemotrophic anaerobic bacteria. Bacteriological reviews, 41(1), 100.

Tichy R. et al. (1998), Solid-state reduced sulfur compounds: environmental aspects and bioremediation. Critical Reviews in Environmental Science and Technology, 28, 1-40.

Torner-Morales F.J. and Buitrón G. (2010), Kinetic characterization and modeling simplification of an anaerobic sulfate reducing batch process. Journal of Chemical Technology \& Biotechnology, 85(4), 453-459.

Torres-Sanchez R. et al. (2001), Corrosion of AISI 304 stainless steel induced by thermophilic sulfate reducing bacteria (SRB) from a geothermal power unit. Materials and Corrosion, 52(8), 614-618.

Trudinger P.A. and Loughlin R.E. (1981), Metabolism of simple sulfur compounds. Comprehensive biochemistry, 19, 165256.

Truong H.-Y.T., Chen Y.-W. and Belzile N. (2013), Effect of sulfide, selenite and mercuric mercury on the growth and methylation capacity of the sulfate reducing bacterium Desulfovibrio desulfuricans. Science of The Total Environment, 449, 373-384.

Turpeinen R. et al. (1999), Influence of microbes on the mobilization, toxicity and biomethylation of arsenic in soil. Science of the Total Environment, 236(1), 173-180.

U.S. EPA ( 1992), Secondary Drinking Water Regulations.

Vallero M.V.G., Lettinga G. and Lens P.N.L. (2005), High rate sulfate reduction in a submerged anaerobic membrane bioreactor (SAMBaR) at high salinity. Journal of Membrane Science, 253(1-2), 217-232.

Valls M. and Lorenzo V.c. (2002), Exploiting the genetic and biochemical capacities of bacteria for the remediation of heavy metal pollution. FEMS Microbiology Reviews, 26(4), 327-338.

van der Zee F.P. et al. (2007), Sulfide removal by moderate oxygenation of anaerobic sludge environments. Bioresource technology, 98(3), 518-524.

van Houten R.T. et al. (1995), Sulphate reduction by aggregates of sulphate-reducing bacteria and homo-acetogenic bacteria in a lab-scale gas-lift reactor. Bioresource technology, 54(1), 73-79.

Vandieken V., Knoblauch C. and Jorgensen B.B. (2006), Desulfotomaculum arcticum sp. nov., a novel spore-forming, moderately thermophilic, sulfate-reducing bacterium isolated from a permanently cold fjord sediment of Svalbard. International Journal of Systematic and Evolutionary Microbiology, 56(4), 687-690.
Velasco A. et al. (2008), Evaluation of feed COD/sulfate ratio as a control criterion for the biological hydrogen sulfide production and lead precipitation. Journal of Hazardous Materials, 151(2-3), 407-413.

Visser A. (1995), The anaerobic treatment of sulfate containing wastewater, Landbouwuniversiteit te Wageningen.

Vossoughi M., Shakeri M. and Alemzadeh I. (2003), Performance of anaerobic baffled reactor treating synthetic wastewater influenced by decreasing $\mathrm{COD} / \mathrm{SO} 4$ ratios. Chemical Engineering and Processing: Process Intensification, 42(10), 811-816.

Wakeman K.D. et al. (2010), Silage supports sulfate reduction in the treatment of metals- and sulfate-containing waste waters. Water Research, 44(17), 4932-4939.

Wang A. et al. (2008), Enhanced sulfate reduction with acidogenic sulfate-reducing bacteria. Journal of Hazardous Materials, 154(1-3), 1060-1065.

Waybrant K.R., Ptacek C.J. and Blowes D.W. (2002), Treatment of Mine Drainage Using Permeable Reactive Barriers: Column Experiments. Environmental Science \& Technology, 36(6), 1349-1356.

Weber A. et al. (2001), Sulfate reduction in Black Sea sediments: in situ and laboratory radiotracer measurements from the shelf to $2000 \mathrm{~m}$ depth. Deep Sea Research Part I: Oceanographic Research Papers, 48(9), 2073-2096.

Weijma J. et al. (2003), The effect of sulphate on methanol conversion in mesophilic upflow anaerobic sludge bed reactors. Process Biochemistry, 38(9), 1259-1266.

White C., Wilkinson S.C. and Gadd G.M. (1995), The role of microorganisms in biosorption of toxic metals and radionuclides. International Biodeterioration \& Biodegradation, 35(1-3), 17-40.

WHO (1996), Guidelines for drinking water quality (second edition), World Health Organization, Geneva, Switzerland.

Widdel F. (1988), Microbiology and ecology of sulfate and sulfurreducing bacteria, in Biology of anaerobic microorganisms, Zehnder A.J.B., Ed., John Wiley \& Sons, New York. pp. 469585.

Widdel F. et al. (1992), The dissimilatory sulfate-and sulfurreducing bacteria. The prokaryotes: a handbook on the biology of bacteria: ecophysiology, isolation, identification, applications, vol. I., (Ed. 2), pp. 582-624.

Willow M.A. and Cohen R.R.H. (2003), pH, Dissolved Oxygen, and Adsorption Effects on Metal Removal in Anaerobic Bioreactors. Journal of Environmental Quality, 32(4), 12121221.

Xu X.-j. et al. (2012), Enhanced elementary sulfur recovery in integrated sulfate-reducing, sulfur-producing rector under micro-aerobic condition. Bioresource Technology, 116, 517521.

Zhao Y.-G., Wang A.-J. and Ren N.-Q. (2010), Effect of carbon sources on sulfidogenic bacterial communities during the starting-up of acidogenic sulfate-reducing bioreactors. Bioresource Technology, 101(9), 2952-2959.

Zhou W. et al. (2007), Effect of limited aeration on the anaerobic treatment of evaporator condensate from a sulfite pulp mill. Chemosphere, 66(5), 924-929.

Zitomer D.H. and Shrout J.D. (2000), High-Sulfate, High-Chemical Oxygen Demand Wastewater Treatment Using Aerated Methanogenic Fluidized Beds. Water Environment Research, 72(1), 90-97. 